\title{
The Role of Silk in the Behaviour and Sociality of Spiders
}

\author{
Bertrand Krafft ${ }^{1}$ and Laurie J. Cookson ${ }^{2}$ \\ ${ }^{1} 472$ Street Lower Coast, Cidex 53, 54710 Ludres, France \\ ${ }^{2}$ School of Biological Sciences, Monash University, Clayton, VIC 3800, Australia \\ Correspondence should be addressed to Laurie J. Cookson, laurie.cookson@monash.edu
}

Received 5 December 2011; Accepted 24 February 2012

Academic Editor: Diana E. Wheeler

Copyright (C 2012 B. Krafft and L. J. Cookson. This is an open access article distributed under the Creative Commons Attribution License, which permits unrestricted use, distribution, and reproduction in any medium, provided the original work is properly cited.

This article describes the links between the production of silk by spiders and their behaviour. Silk allows the spider to change its physical environment, which in turn leads to behavioural changes and impacts in the new environment. The feedback between silk and the animal producer can explain the architecture of spider webs and their adaptation to the environment, by referring only to stereotypic stimulus-response reactions without necessarily resorting to a "representation" by the animal of the structure it builds. Silk can act as a means of protection against environmental stress, a snare for prey, a means of locomotion, and also as support for chemical signals or to act as a vector of vibratory signals. These last two functions have undoubtedly played a key role in spider socialization and explains the phenomena of group cohesion, collective decision making, and the coordination of activities, without resorting to mental "representations" for the overall situation. The bulk of this review describes silk as the chief agent directing the construction of traps, communication, social cohesion, and cooperation amongst its producers.

\section{The Production of Silk: A Capacity Widespread amongst Arthropods}

Only arthropods produce silk, and insects of almost every order secrete silk-like proteins. For example, Dictyopteran mantids enclose their eggs in a capsule that has a chemical composition similar to silk. However, only a few groups have developed an advanced behaviour for silk weaving (Hymenoptera, Lepidoptera, Embioptera, Thysanoptera, Trichoptera, and some larvae of Diptera) [1]. This ability is widespread among arachnids, particularly spiders, including some fossil species $[2,3]$, and may have evolved from an onychophoran-like ancestor $[1,4]$.

The only animal silk used commercially to date is from a moth caterpillar, the silkworm Bombyx mori. But many other Lepidopteran larvae produce a silk cocoon into which they withdraw during metamorphosis. Some social larvae construct silken shelters to house the colony $[5,6]$. Silk production during pupation is also characteristic of the larvae of Hymenoptera, while some adults are also capable of producing silk, such as the Sphecidae [7]. This larval capacity also occurs in the workers of certain ant species. The best known are Oecophylla which use their larvae to "sew" leaves together, thereby forming a compact nest for the colony. Some other ant species also build silken nests [8-12]. Camponotus senex is a South American tree ant that has behaviour similar to Oecophylla [13]. However, for the ant Melissotarsus emeryi of South Africa, it is the adults that directly produce silk from glands located in the oral cavity [14].

Many other more cryptic arthropods produce silk. The aquatic larvae of Trichoptera (caddisflies) build bags assembled from sand grains or plant fragments using silk. Some of them (Hydropsyche) even develop net-like traps to capture small prey driven towards them by the current $[15,16]$. The social Embioptera use silk secreted from metatarsal glands on their front pair of legs to produce silk-lined shelters [1720]. The social Thysanoptera sew leaves together to form a common shelter [21]. Social psocids (Archipsocus) weave silken roofs over their feeding area [22].

Among the arachnids, spiders are the most famous producers of silk. But some mites also spin webs as a nest to house the group [23-26]. Male pseudoscorpions guide females to their spermatophore by weaving a net, as a kind of corridor narrowing towards the tip and composed of silken threads $[27,28]$. They also build nest protections using silk glands at the end of their chelicerae [29]. 


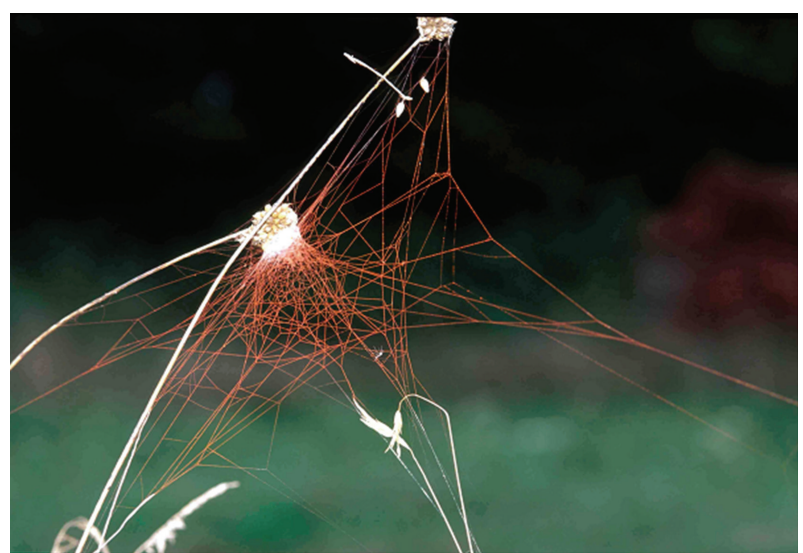

FIGURE 1: The retreat of Araneus quadratus. The threads of the web are revealed by highlighting them with colour (Photo Krafft).

The variety of species that produce silk in such a variety of unrelated groups demonstrates the adaptive significance of this material in the prevailing environment. A variety of structures are produced, ranging from simple protective packaging (cocoons) to the geometric orbs of certain spiders, through to web sheets and three-dimensional structures where several aspects are curiously reminiscent of the architecture of man-made structures such as suspension bridges [16].

Spiders produce different types of silk, such as a nonsticky dry thread that tracks the spiders progress (any spider in the Araneomorphae that moves leaves this security thread behind it), strong threads for the framework and rays of geometric webs, sticky spiralling threads for capturing prey, cribellum silk whose structure is particularly complex and which adheres to the prey like "velcro," parchment silk, and silk used in the manufacture of cottony egg sacs. A spider can produce up to 8 different kinds of silk. Their functions are as varied as the structures produced [30]. Furthermore, the spider can attach a thread to any substrate or existing thread with ease. This diversity and flexibility of use justifies the extensive research conducted on the fine structure of silk $[16,31-36]$, and its physicochemical properties [37-46].

\section{Silk as a Protective Material}

The original function of the silk secreted by spiders was probably to make cocoons to protect eggs and build individual shelters. Many solitary spiders build silken retreats that are bell-shaped tubes within vegetation or under stones [30] (Figure 1). The walls of these structures provide effective protection against wind and rain. Silk linings can also resist water, allowing some spiders to live in areas subjected to flooding by forming an air bubble in which to live until the water recedes. Argyrodes even lives permanently under water within a silky diving bell. This spider traps a bubble of air, and gas exchange between the air and water occurs through the wall of silk, which allows sufficient oxygenation and carbon dioxide removal.
Silk is also a material that can modify certain elements of the environment. Many spiders live within the cubicles made from leaves bonded with silk. This is particularly the case for Larinioides cornutus, which frequently lives amongst reeds lining ponds. The reed's leaves are bent by the spider using a succession of silken threads which, by narrowing, increase the curvature so that the distal part of the leaf becomes located near the proximal end. Caterpillars use the same technique.

All spiders enclose their eggs within a silken egg sac of varying complexity. In temperate regions, the young of most species hatch in autumn (fall) but remain in hibernation within the egg sac until they emerge in spring. They spread out a few days later after a short gregarious period. These egg sacs are often composed of several types of silk, as is the case for Argiope bruennichi. The outer part of the egg sac is a tough leathery shell, followed by a red silken wad (red-brown flosssilk), and finally an envelope of white silk containing the eggs. Agelena labyrinthica manufactures a large cell in which the female stands until her death in autumn and includes a second chamber of the same shape that contains a basket of eggs.

Silk is used to protect the colonies of social spiders [47-49]. Anelosimus eximius is a social spider from Guyana that constructs large complex webs with volumes ranging from 0.001 to $1,000 \mathrm{~m}^{3}$ [50] (Figure 2). Colonies reaching $100 \mathrm{~m}^{3}$ are common. These structures function primarily to capture prey. If the web is disturbed by a predator such as ants, predatory wasps, and other species of spiders, their vibrations are readily transmitted through the silky network allowing A. eximius to mount a coordinated defence. Small emigrant populations (20 to 50 individuals) with incomplete webs can be quickly decimated by Ponerine ants, while these attacks are useless when the web becomes functional. The arrival of a predatory wasp often attracts a large number of spiders, which makes it dangerous for the wasp to continue its attack. To capture a spider, the predator must first isolate an individual. On the other hand, the senior author has observed in Gabon the total destruction of a colony of over $20 \mathrm{~m}^{3}$ of another species of social spider, Cyrtophora, in the space of one night by raiding Magnan ants. The protection of social spiders within these large webs can also be ineffective against some vertebrates, especially birds that remove silk from the colonies for their own nests or catch spiders for food.

Nests of social spiders of the genus Stegodyphus are more compact. The spiders live within a dense mass of silk whose protective effect against vertebrate predators improves when the nest is larger $[51,52]$. Contrary to popular belief, these nests do not protect against changes in temperature and humidity. At most, they offer some protection against the wind and rain [53].

\section{Silk Used to Build a Snare and to Exploit the Environment}

Many species of spiders are wanderers that pursue their prey using visual information or the vibrations produced by prey as they move through the air or upon soil [54]. They often 


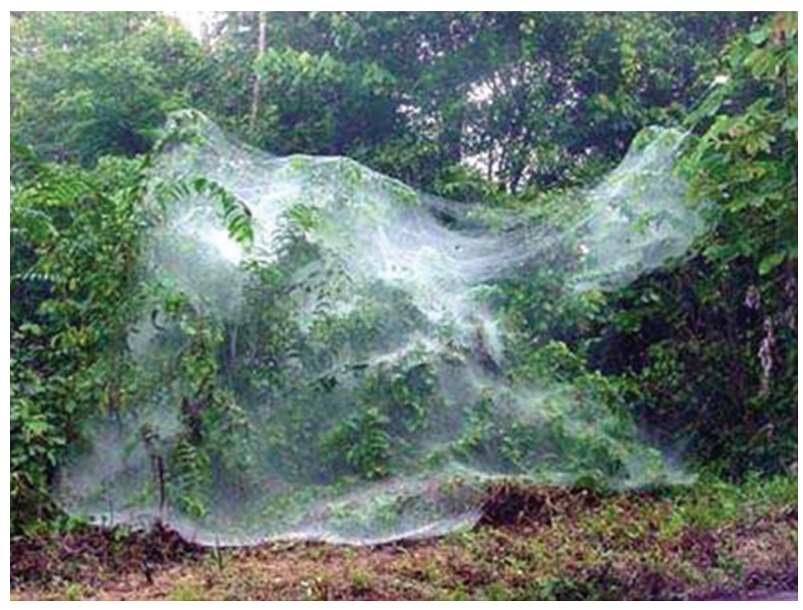

Figure 2: Colony of Anelosimus eximius from Guyana (5 m long, $3 \mathrm{~m}$ high; Photo A. Bernard).

build silken retreats in vegetation, or under bark or stones, but may move frequently.

It is generally accepted that the web-spinning species evolved from an extension of these benefits in the use of silk. In developing a trap, the spider changes its environment in order to exploit certain food resources. These traps are static nets that can only catch mobile prey, thereby requiring the spider to select a site that is sufficiently rich in resources for web construction. Despite the fact that spiders can change sites if necessary, the construction of a web is an important investment by sedentary web-spinning species. The architecture of these traps is varied $[16,55,56]$.

The function of some webs is simply to provide a warning. The thread, or a sheet of silk attached to a retirement, transmits the vibrations produced by prey to the spider. The trap allows the prey to stay on its course and does not restrain it. The most notable examples are spiders from the genera Segestria and Uroctea. Several threads radiating from their retirement run one or two millimetres above the substrate, supported by small columns of silk. These posts tend to alternate their attachment to the thread left and right as is sometimes the case for the overhead lines of electric trains. The threads are not sticky but made of dry silk, yet perform their warning function perfectly because they lack any contact with the substrate.

Other traps have the function of both warning and interception. Many traps consist of a three-dimensional network of dry threads above a horizontal web sheet. This is the case for the Agelenidae and Linyphiidae. In some cases, the sheet may be a radiating geometric structure as in Cyrtophora. The prey is temporarily halted by the tent-like network of threads and may eventually fall onto the web sheet. Although the threads are not sticky, they adhere to the prey (especially if it is hairy or adorned with spines) like cotton wool [57-59]. But the retention time of the trap is short so the prey can escape if the spider is slow or absent. These webs are designed as permanent traps. The spider simply repairs them every day. However, it sometimes abandons the web to find a new location and construct a new trap $[60,61]$. Such reconstructions

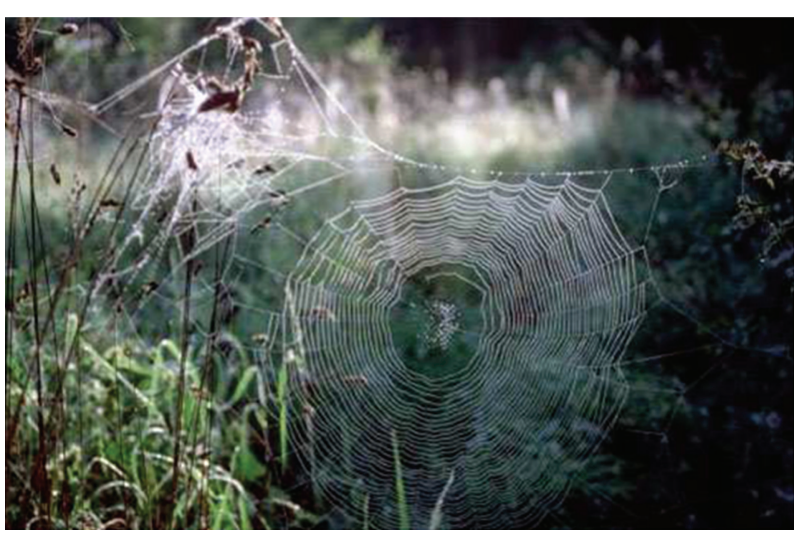

Figure 3: The orb-web of Araneus quadratus (Photo Krafft).

are expensive and can require 19 times more energy than is expended by simply maintaining an existing web [62].

Finally, some webs have the function of warning, interception and retention. These include the classical twodimensional webs of the orb spiders (Figure 3), such as Araneus diadematus and Argiope bruennichi. The orbs are constructed from a set of spokes that support a sticky spiralling silk thread covered with droplets of glue. The complex geometry of these structures has captured the imagination and allows the spider to weave large webs with the minimum of silk. The capture area is huge compared to the amount of material used. However, this trap is fragile and deteriorates quickly. Any prey that is caught leaves a hole in the web. It is, therefore, rebuilt regularly, often daily. But as these spiders ingest the old (nutritious) web before building a new one, the energy expended is no greater than if the web was simply maintained $[63,64]$, which also allows them to then change sites easily if there is a reduction in the availability of prey [65]. Some cribellate species (e.g., Uloborus) develop similar traps except that the sticky spiral is replaced with a cribellum thread (hackled band), which relies on fine fibres on the threads to entangle rather than adhere the prey [66]. As well as orbs, many permanent three-dimensional traps have similar functions. Some sections of the network of threads can be sticky (Theridionidae) or composed of cribellum silk (Dictynidae, Amaurobiidae). This allows smaller prey to be captured permanently, even if the spider is not immediately involved. While there are differences in the capacity of different adhesive silks, these are largely offset by the response of the spider, usually rapid in traps with short retention times and slower for others [59].

All of these web-designs in silk have a significant impact on the behaviour of spiders. Not only do webs allow the capture of prey, but they give the spider an expanded perceptual field. The spider not only discerns the objects it touches or that pass nearby, but also anything that touches the web. Rain, wind, a leaf falling on the web, or large prey that passes through the web can all be detected. Webs are a true extension of the sensory organs of the spider, thus giving it improved control over its environment $[67,68]$.

In web-spinning species, the spider is notified of the arrival of prey by the broadcast of vibrations through the 
silky network upon prey impact and its attempts at escape $[67,69]$. These vibrations are complex phenomena. An impact produces a strong transient signal, beating wings produce sinusoidal vibrations, and web rupture from struggling prey causes sudden variations and sporadic signals. The spider can probably identify the type of prey on the basis of these signals, as shown experimentally by reproducing the same response at given frequencies [70-74]. In geometric webs, these vibrations converge on the hub [75] being borne mainly by the rays [67]. Spiders are well endowed with mechanoreceptors such as cleft bodies and lyriform organs that are sensitive to vibrations [76-79] and allow the spider to locate its prey. The distribution of vibration receptors on eight legs facilitates orientation as each appendage will measure slightly different distances and signal intensities according to the exact positioning of the prey [80]. In orbweaving spiders, this orientation is facilitated even further through the rays $[77,81,82]$. At its hub, the spider can easily detect the area of web with prey. In contrast for species exploiting a web sheet, locating prey may require two to four shifts in direction by the spider before it can find its victim [83]. These reassessments are made during short stops. An immobile prey cannot be located, unless the spider sends vibrations through the web by pulling its threads. This process, also used by orb-weaving spiders, is akin to echolocation used by bats and not only locates the object on the web but also helps to evaluate its mass [77].

When the spider comes into contact with its prey, it paralyzes the prey by injecting venom through the chelicerae. Further, some species such as Araneus, and more dramatically Argiope, wrap the prey in broad ribbons of silk. The wrapping may occur before or after the bite. Faced with prey that have their own defensive systems (e.g., Orthoptera equipped with spiny legs, or stinging Hymenoptera), Argiope immobilizes its prey using a silky "straitjacket" before moving closer to bite.

In some cases, as with Argiope, the web is decorated with wide bands of white silk in the shape of a zigzag or disk (the stabilimentum) on or near the hub [30]. This intriguing structure has been likened to a system that might protect against predators $[84,85]$. It can make the spider appear larger or provide camouflage to hide the exact location of the spider [86]. The stabilimentum is frequent and large in cobwebs where spiders are well fed while the reverse is true for poorly fed spiders. Its presence can reduce the catch rate of webs by $30 \%$. In contrast, $70 \%$ of the webs lacking a stabilimentum can be destroyed by the passage of birds compared to $30 \%$ when a stabilementum is present $[87,88]$. Other results, partly based on laboratory experiments, suggest that the stabilimentum acts as a system that attracts prey because it reflects ultraviolet light [89-92]. However, some prey are able to avoid webs based on visual information $[93,94]$, and the function of the stabilmentum is still controversial [86].

The production of a fixed web that can only capture mobile prey has an important effect on the behaviour of spiders. Made sedentary by the web, it is imperative that the spider selects sites rich in prey. A few changes in sites, about once a month for Agelenopsis aperta (web sheet builder), is especially costly since it involves the complete reconstruction of the web and retirement. However, it allows the spider to adapt to possible variations in ecological conditions and food requirements. The selection of sites based on physical characteristics of the environment and its fauna has been demonstrated in Agelenopsis aperta [60] and some orbweaving species [95], as the sites selected by the spider were different from random sites. The sites differ especially by their richness in prey, the presence of bushes, land depressions, and attractive elements for prey such as flowering plants or organic waste. Moreover, during its development, the spider seems to become increasingly demanding in its selection. But all of the information that spiders take into account are poorly known.

Prey caught by a web is lost to its neighbour. There is, therefore, a potential risk of competition that has been verified. Under certain conditions of population density, spiders do indeed show an even spatial distribution [60, 96-98]. In Agelenopsis aperta, these "territories," which can reach several square metres, have a surface size inversely proportional to the amount of prey available and if by chance two spiders exploit an area equivalent to one "territory," this can result in a $40 \%$ reduction in the catch rate for each individual. One of these individuals will then leave the location earlier than might be expected under normal circumstances [60, 99]. Because of these movements within a population, there are relatively frequent meetings between spiders, and one may attempt to steal the web of the same species. The protagonists can use vibratory signals as threats during agonistic interactions. If size differences are not too great, this dialogue of vibration escalates until one gives way [61].

By its presence in the environment, the web reveals the site chosen by the spider based on ecological characteristics. It also tells us about the perception that the spider has of its environment. In fact, spiders are able to change the size of the web as a function of prey availability [100]. In prey-rich environments, the webs are smaller than in poorer environments. This adaptability in web size suggests that the spider can make an assessment of prey availability, leading to "decisions" on whether to build a large or small web. This adaptation can be explained by a simple mechanism, not involving complex cognitive processes, at least in the spiders that build sheet webs (see below: construction of the web).

Spiders are not the only arthropods that can weave silk snares. Some aquatic larvae of caddisflies construct traps between stones and capture prey driven by the current [15, 16]. There is also the rather exceptional case of a predatory larva of Diptera in Australia Arachnocampa luminosa [1, 101], which weaves a trap made of sticky threads hanging from a horizontal silk line.

\section{Silk as a Means of Communication}

Like many animal species, spiders communicate via chemical signals or pheromones [102]. Those with well-developed vision (Salticidae and Lycosidae) also display visual signals such as by waving their legs in specific choreography [103105]. Tactile stimuli between spiders are often mentioned incidentally in the literature but have not been studied 
objectively. At first glance, these modes of communication do not differ from those of most other animal species.

The unique properties of spiders arise primarily from the exploitation of their remarkable sensitivity to vibrations [77]. Indeed, this sensitivity to vibration is used to detect prey and also serves in social and sexual communication. Many species communicate while wandering, reconciling sexual and agonistic encounters, through the vibratory signals produced by the movement of their legs or abdomen and as transmitted by the substrate [106-115]. Web-spinning species have taken advantage of the capabilities of the silken thread to transmit all kinds of vibrations. Males coming into contact with a female's web produce specific vibrational signals, by pulling the threads or by vibrating their abdomens, that is to say, by using the same type of behaviour as wandering spiders [116-124]. These signals are specific and may lead to acceptance by the female if she is receptive. Vibratory communication at distance allows the male to decide whether to approach or avoid the female. Often a dialogue is established between partners, strengthening the system of partner identification within a species and improving its effectiveness as a species barrier.

Silk also has an influence on chemical communication in spiders. Females are capable of depositing a chemical trace on the ground or substrate, which initiates courtship behaviour in male Lycosides, without allowing their orientation toward the female [125]. Their originality lies in the fact that females of almost all species can combine their sex pheromones with their travelling thread and the threads of their web. A male is thus able to identify a thread of silk produced by a female adult, sometimes even a female subadult, and to monitor them using both chemical and mechanical information. This method is used by both wandering and web-spinning species [118-120, 122, 124, 126-142].

While this mechanism seems well suited to wandering spiders, it begs the question of effectiveness in sedentary webspinning spiders. However, observations in the laboratory on Tegenaria showed that while remaining faithful to their web home females regularly leave it and move about their immediate environment for short periods. During these wanderings females leave a trail of threads behind, which converge towards the web allowing the orientation of males [143]. In orb-weaving spiders, many radiant threads have no direct connection with the web but lead directly to their retirement [98].

It is plausible that the threads also influence the territorial distribution of spiders. It has indeed been demonstrated in some Salticidae spinners, that females are able to distinguish between their own threads and those of a foreign female of the same species $[144,145]$. In a choice situation, they spend more time on their own silk. But they also spend more time on the silk of an unknown female than of a known congener. Orb-weaving spiders could also use the threads to detect the arrival of an intruder.

Sexual communication in spiders is even more complex because it often combines chemical, visual, and vibratory communication. Due to the dispersion of individuals in the environment (except in social species) and their reduced mobility compared with flying arthropods, encounters between the sexes cannot be left to chance. It is usually the male that travels in search of the female, which is easily explained in web-spinning species because, after mating, the female needs to remain with its web and feed for egg maturation and the construction of the egg sac. Selecting a new location would be expensive. Although not researched in the literature, it is apparent that the males of wandering spiders also spend more time searching for females, even though the females are less bound to a specific site. In all cases studied so far, the coming together of the sexes is based upon the use of chemical signals, volatile pheromones, and/or an association with silk. In the latter case, the male also uses mechanical information in silk. As the partners converge, they can also utilise vibrational and visual communication. Visual communication or vibration through the substrate is utilised by Lycosidae, visual communication is used by the wandering Salticidae, and vibratory communication through silken threads is used by the web-spinning species. It is therefore, an addition of signals using different vectors, which refines the identification of partners and avoids disruption from the vagaries of the environment. In Tegenaria species (spinning species), a combination of chemical signals and vibrations enhances the species barrier, and the absence of one type of signal can be partially compensated for by the presence of another [116].

Social life has apparently changed this system of communication among nonterritorial species. By living in a "telephone network," it is easy to see that the males of social, territorial, or nonterritorial species use vibrational signals to woo females, as is the case for the solitary web-spinning species [146-148]. However, it appears that chemical signals associated with female silk have no effect in Mallos gregalis (social nonterritorial), which seems quite logical given that the males live permanently within the webs woven by females [149].

\section{Silk as an Organiser of the Behaviour Needed to Build a Trap}

A web's geometry provides a record of the behaviour of the spider during its manufacture. The complexity of the architecture and the consistency of its production have captured the imagination of biologists, who suggested in the early 1900s that the spider must have a strict plan or instinctive map for construction in its "head." It is true that construction takes place through a succession of specific acts [150-152].

Before building its web, the spider explores the media available. It then weaves the primary rays and first threads of the framework, leading to a draft hub that marks the convergence of the primary rays. It then constructs the secondary rays to complete the frame and finally it lays the tertiary rays. Then, beginning at the hub, it begins constructing the provisional spiral thread, which increases in pitch from the hub to the periphery and is made of dry (non sticky) threads (Figure 4). Finally, returning from the periphery to the hub, the spider weaves a sticky spiral thread which is neither regular nor tight. These steps lead the spider 


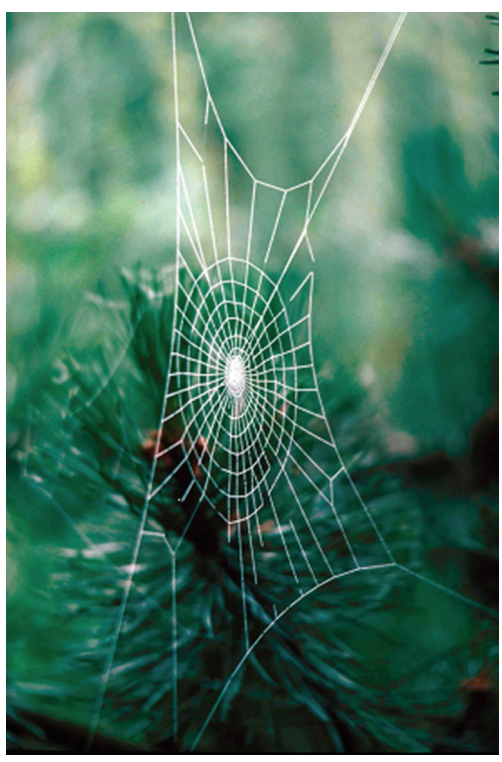

FIgUre 4: Web showing the primary spiral (Photo Krafft).

to produce a structure of complex architecture that has been extensively described in the literature [153-157].

Nevertheless, as it was difficult to accept that a "representation" of this complex architecture and its implementation could be contained within the head of a spider, we tried to explain this construction through a succession of strictly stereotyped and sequential acts. We attempted to describe the spider as an example of automatic genetic programming where each stage of construction was well planned. But this rigid concept of their behaviour had to be abandoned in light of the experiments that were conducted.

Despite its exploratory behaviour before the construction of a web, the spider does not seem to develop a "representation" of the available media. Indeed, the first web built in a new environment is smaller and more uneven than in the finished product (the peripheral attachment points for the rays are not in the same plane). Only gradually does the spider adjust the attachment points of the main threads to produce a larger and flatter web. The spider seems to require a succession of tests before reaching its perfect construction $[158,159]$. We can at least deduce that the spider does not "anticipate" the final design of its web from the beginning. During successive reconstructions, it modifies some threads in the frame while maintaining others as aids for travel. As the spider always leaves a thread behind it, one can imagine that flatness improves spontaneously when it takes shortcuts between points previously separated by a third thread that lies outside the plane. This is only a hypothesis, but one that deserves testing, especially in light of what we know about the construction of web sheets (see below).

Independence between the successive steps involved in web construction was highlighted long ago. However, the importance of this phenomenon was not always understood due to the lack of appropriate concepts. The classic experiment was to cut rays during the construction phase. If the spider was following stereotypical acts according to a strict sequence, the spider that had placed the expected number of rays should continue its work according to a genetic program and, therefore, produce an incomplete web containing the damage. However, the spider detects the missing rays and replaces them. Conversely, if we add artificial rays the spider builds fewer of its own. In addition, the spider is able to revert to earlier constructional behaviours as required. If we destroy rays while it is engaged in the latter steps of constructing the temporary spiral, it replaces the missing rays $[160,161]$. This suggests that it is the work already performed that controls manufacturing behaviour. The behaviour of the spider is guided by the silky structures already present. König, therefore, proposed that all the elements needed to explain web construction were processes of stigmergy. This idea was supported at the time by Szlep [162] who demonstrated the absence of a strict sequential organization in web manufacturing behaviour, that is, there was independence of action between each step. The concept of stigmergy was still to be established [163].

Another important observation has not had the impact that it deserves. A spider placed on a partially developed web prepared by a congener continues to work upon the web by immediately adopting the appropriate behaviour needed for its completion [162]. This confirms the independence of the acts (the spider notes its environment before engaging in the steps needed for web construction) and the fact that they are controlled by the existing web structure. Further, it shows that the behaviour of an individual can be driven by the silky structures built by another individual, which is the very principle of social stigmergy. These results have been confirmed by showing that a small spider placed on the partial construction of a large web will also finish the design larger than it normally would [164]. Nobody at the time realized that these results also demonstrate that solitary spiders could potentially cooperate in web building, as even though the individuals do not work simultaneously, the sum of their efforts is a completed web. One might ask why they do not cooperate spontaneously in nature. A possible explanation is territorialism, which is partly based on genetic determination [165-167] and was probably heavily selected during the evolution of some spiders. But the geometry of the web is another possible explanation. The two spirals are each composed of a single thread that can only be installed by one individual at a time.

Also, the hub is a strategic point that can be occupied by only one spider. Intrigued by the scarcity of social species, biologists have wondered about the origin of sociality, but with little or no reference to the mechanisms responsible for their individualism.

The work conducted 60 years ago on the construction of webs was repeated 20 years later, and confirmed that the spider gains information from the silken structures already in place. For example, it takes into account the angle between adjacent rays, between rays and the provisional spiral, and the distances between the rays and successive spiral turns [168]. They also confirmed the flexibility of the manufacturing behaviour, however, stereotypical the acts [169]. This flexibility is due to the independence of action between 
different acts, due to the fact that the spider primarily uses information from local existing structures to "decide" its correct behaviour [170]. The winding direction of the provisional spiral, for example, influences the placement of the sticky spiral [171]. These processes allow, among other things, the spider's web to adapt to environmental conditions [172].

Factors other than the existing silken structure also have an influence on web building behaviour. Gravity is responsible for centring the hub in the upper part of the web $[66,173]$. The surface area of the web above the hub is always less than the surface area below. Spiders with weights glued to their backs increase this asymmetry [174]. The structure of the environment, such as the materials available, also influences the construction of the web [172].

However, it is impossible to reduce web manufacturing to a simple automatic response to external factors. The web of each species has a specific architecture and the webs of similar species have more in common than those of species from different genera [175]. Some characteristics of the webs are independent of age and size of the spider [176]. Moreover, the construction of a web by a young spider requires maturation of the behavioural mechanisms [177, 178]. Thus, we cannot exclude an internal programming that at least prevents the spider from reacting in a random manner to stimuli. Even in the context of stimulus/response reactions, the information collected is processed and will help generate a response. Information processing can be altered by drugs that cause specific alterations to the architecture of the web, a change in the positioning of the hub or the appearance of irregularities [179-181]. It may also depend on the situation. Gravity has an influence on the laying of the provisional spiral, but not the sticky spiral, probably because the spider bases its weaving of the sticky spiral on the presence of the provisional spiral [171]. Moreover, the provisional spiral maintains constant angles with the rays and does change pitch, while the sticky spiral maintains a constant spacing between successive turns which do not change pitch [182]. These phenomena again demonstrate the role of existing structures in determining subsequent behaviour. The spider may also partially compensate for physical disabilities. After a leg is lost, it regenerates at the next moult but with reduced size. This reduction in the length of one or more legs affects the spacing between the turns of the sticky spiral but has no effect on the installation of the provisional spiral. These results demonstrate that the behavioural rules governing the installation of the two spirals are different [182]. For the installation of the provisional spiral, the spider takes account of the angle with the rays, while for the sticky spiral, it weaves according to the distance that separates it from the previous spiral. Finally, the amount of silk available in the silk glands is another factor that determines the size of the web [183].

With improved modelling programs, it may be possible to explain these variations by simple adjustments to the various quantitative or qualitative feedback stimulus/response reactions involved.

The web is the geometric reflection of complex animal behaviour, and thus the material of choice for studying this behaviour. It is not surprising that several researchers have attempted to model the web building behaviour of spiders. In 1965, Witt stressed the importance of this biological model while adding, however, that while it was easy in principle to model the manufacturing behaviour, that is to say, to develop a model mimicking the construction of a web, it would also be difficult to validate the different stages of programming [176]. The first test model assumed that the spider took into account the angles between the spiral, rays, and the previous lap of the spiral [184]. The model weaved the author's virtual web and it resembled natural webs with particular "Greek" architectures (when the spider comes too close to the frame in the upper part of the web, it turns around; it, therefore, produces more spiral thread in the lower than upper part of the web). The author stresses that this model does not prove that the rules introduced in the model are identical to the behavioural rules of spiders. But this result successfully demonstrates that it was possible to obtain a complex structure on the basis of simple principles.

It was only recently that attempts at modelling have grown. Based on previous results, Vollrath developed a model of virtual spider manufacturing that takes into account the angles between the threads and radii, distances between successive turns of the spiral, leg length, and other parameters of varying complexity gleaned from the architecture of the web $[185,186]$. Nevertheless, all the rules introduced into the model are simple rules based on the responses of the virtual spider to local information, apart from the memory of the last segment of the thread's run [187]. The model produces very similar formations to natural webs, even though it contains no rules on the overall architecture of the web. Moreover, the artificial webs obtained are suitable for the space available, so, therefore, accommodate local landscape features [188]. The architecture of the web is an emergent property of the system [187]. Finally, the virtual spider which has one leg "regenerated" constructs a web in accordance with those woven by living spiders that have undergone the same treatment [189]. A set of simple and stereotyped responses to local information makes it possible to achieve an overall plastic behaviour, demonstrating that rigid acts in isolation do not prevent flexibility and confers robustness to the system.

This model successfully demonstrates that it is possible to obtain a complex geometric structure from simple behaviours, without having to explicitly specify the overall final architecture of the web, and that the spider's response to local information is sufficient to adapt the web to environmental conditions. However, doubt remains as to the validity of the stimulus/response reactions in the model. The behavioural rules used in the model were derived mainly from the geometry of the web and observations of spider behaviour, and are not, or only slightly, based on stimulus/response interactions verified experimentally. But we must recognize that the web geometry is complex and it is technically difficult to identify all the elementary interactions governing their construction.

The geometric orb web is traditionally opposed to those webs labelled "irregular." These irregular webs, however, also obey architectural rules as it is possible to distinguish the webs of the different species. But these rules would seem to 


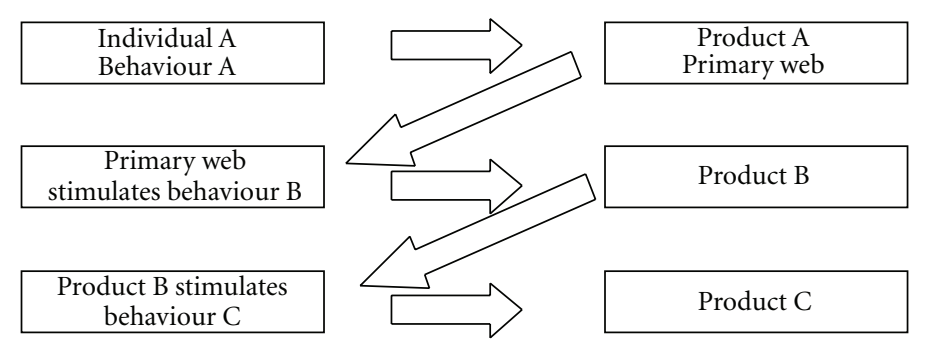

FiguRE 5: Processes in self-stigmergy. The behaviour of an individual is driven by the product of its previous actions (based on Grasse [163]).

be simpler, which makes them more suitable for modelling [190]. Unfortunately, few researchers have been interested in their construction [191].

The web of Agelena labyrinthica consists of a horizontal sheet topped with a three-dimensional network. A retreat tube open at both ends leads onto the horizontal sheet. Every thread of this trap is made of dry silk. The network intercepts airborne prey that fall rapidly onto the sheet where they are captured by the spider.

This web is constructed in several stages. In the laboratory, in a horizontal square glass box empty of any support structures, the spider firstly weaves an outline of its retirement amongst a tangle of threads in a corner, and an outline of a sheet in the form of a framework of threads that are more or less horizontal. Construction continues through the completion of the retirement and the final sheet layer. The sequential order of these structures is variable, which reveals a certain independence of action.

As in the case of the construction of geometric orb webs, structures built beforehand steer the subsequent behaviour of the spider. Because of the shape of the box, the spider builds its retirement in one of the 4 corners of the box. If we allow a spider to build an outline of its retreat in one corner, then remove the spider and turn the box $180^{\circ}$ in a horizontal plane to eliminate any possible action from external factors, and replace the spider which in the meantime has built a complete web in another box, it uses the existing draft outline to develop its final retreat.

The same approach during the construction of the framework for the horizontal sheet shows that the height at which the spider weaves the first draft of its web determines the subsequent position of the final web.

Independence between the various steps necessary for construction is also demonstrated. If the web is partially destroyed, the spider will rebuild the missing part, web, or retreat, without changing those parts that were intact.

These results suggest the involvement of a process similar to the stigmergy described by Grasse [163] for explaining the construction of nests and mounds by termites, except that in spiders it uses interactions between itself and the structures it has already built rather than between these structures and congeners (Figure 5). It is, therefore, a "self-stigmergy" and not a real social stigmergy, as is also the case in birds [192]. This distinction may seem subtle, but it makes sense when one examines the origin of cooperative processes in the emergence of sociality (see below).
These simple mechanisms do not explain all of the architecture of the web, such as the appearance of the sheet, network and retreat. Surveys conducted in nature show a relationship between the provision of materials and these three elements. An analysis of the vertical plane of a web reveals a heterogeneous distribution of vegetation, the latter being less numerous above than below the web.

The sheet is built on the border of a medium density of vegetation below, and a more open environment above. In addition, the height of the three-dimensional web is correlated with the height of overhanging vegetation. The webs may, therefore, take different forms depending on the configuration of the environment.

Any spider that moves leaves a thread along its path. During these trips, it often fixes this thread to a support. On a flat surface, the spider has a constant probability of fixing this thread at a constant distance, as is the case in the social spider Anelosimus eximius [193]. But the presence of bumps on the surface increases the frequency of attachment, as shown by measuring the lengths between each attachment point. Roughness, therefore, encourages a moving spider to fix its thread to supports.

It is easy to demonstrate the influence of these environmental factors on web building by placing spiders in an artificial environment composed of a high density of small supports and a low density of large supports. In such environments, the spider systematically builds its web at the border between the dense environment represented by small supports and the open environment represented by the large supports. A change in the height of the small supports causes a change in the height of the web sheet, while the height of the network is determined by the height difference between small and large supports. In addition, a cardboard shelter mimicking a rolled leaf systematically determines the position of the retreat. This shelter can also have a slight influence on the position of the sheet. If positioned below the boundary between dense and open environment, the spider will lower the level of the sheet.

We can, therefore, formulate the following hypothesis. Moving randomly in the environment, the spider becomes trapped by a particular density of vegetation due to the frequency by which it fixes its thread to supports, leading to the construction of a draft retreat. Radiating from this site, it would reach the tops of the supporting plants and its thread would join them together. The most numerous threads appear at the border between the medium density 

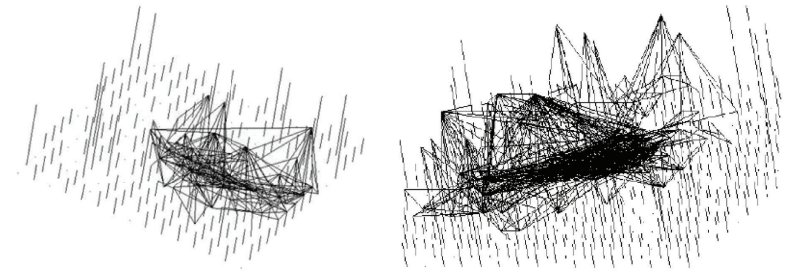

Figure 6: Silken structures produced by the model, where vertical lines represent vegetation with differing heights. Showing a horizontal density (sheet), topped by a network [190].

of plant cover and the open. This appears a draft sheet. The location of the fewer overhead supports in the more open area is responsible for the appearance of the irregular network which tops the sheet. While it is easy to develop such a hypothesis, which implies that the spider has no knowledge of the architecture of the structure it will build, it is more difficult to verify experimentally. In this situation, modelling can be of great assistance.

The proposed model consists of a virtual environment with three types of supports, supports with zero height corresponding to flat ground, small supports that occur in high frequency, and fewer large supports, thus mimicking natural conditions $[190,194]$. The rules imposed on the virtual spider are very simple. It may move at random, fixing the thread that traces its journey over the tops of the supports, in agreement with previous results (high probability of fixing to the tops of supports and low probability of fixing close to the flat ground). Unlike attempts to model the construction of geometric webs, these rules do not imply any assessment of the angles between the threads but assume it is the environment that determines the architecture of the web. In addition, these steps all correspond to the stimulus/response reactions that have been demonstrated in spiders. Despite their simplicity, these rules are sufficient to produce a structure that has some similarities with the "irregular" webs observed in nature. It is sufficient to produce a draft sheet and network.

The result nevertheless is far from perfect as the virtual structure occupies all of the space available when in nature webs have a finite size within infinite space, and while the network appears accurate, the virtual sheet remains a loose dishevelled framework. This suggests that there must be a mechanism that also limits the movement of spiders. One can certainly imagine various rules such as "return to shelter regularly." But knowing the role of silk in spiders, we can also assume that they are trapped by their own silken structures because of a possible attraction to silk.

By introducing only one additional rule in the model, a factor for the attraction of silk, we can vary the size of the web and obtain a virtual web that is limited in size and where the sheet has strong demarcation (Figure 6) [190]. This attraction leads to a certain probability that the spider will choose to follow an existing thread. Placed on a base already connected by a thread to one of eight adjacent supports, the spider is more likely to approach that support over the remaining seven. This rule "traps" the spider in such a way that it remains within existing silken structures. The strength of this attraction modulates the size of the web. Moreover, for a given number of excursions, it determines the density of the sheet.

The attraction for silk has been demonstrated in Agelena labyrinthica, validating the model. In a binary choice situation (T-maze with the two arms providing the test options), the spider spends more time on a substrate covered with its own silk than on a blank substrate. This attraction for silk is further regulated by the state of satiation of the spider. A satiated spider spends more time on a silken substrate than a hungry individual, while the frequency of travel within the experimental device does not change (the spider is not simply resting on the silk). As the silk used is produced by spiders reared under standard conditions, one can deduce that it is the responsiveness of individuals to the silk that has changed, rather than there being any differences in the silk "bait."

We know that spiders are able to integrate a variety of information to select their construction site $[60,61,156$, $195,196]$ and to modulate the structure of their web based on various environmental factors [197-200] such as prey availability [201-203] and frequency of damage from large nonprey animals [65]. Finally, in orb-weaving spiders, the presence of prey induces the spider to anticipate the time when it should build its web [204]. These studies concern spiders that rebuild their geometric webs daily and can therefore easily adapt this behaviour to changing environmental conditions.

These skills in adaptability have been little studied in species that produce irregular webs that are built to last. Nevertheless, several environmental factors (rain, wind, prey) constantly destroy or damage these webs and can reduce their volume by 7 to $11 \%$ each day. A vacant web can be completely destroyed in 15 days. This damage forces the spider to weave every day to maintain its trap, producing 5 to $15 \%$ of the silk originally invested in its total construction [62].

However, it has been shown for a species of Eresidae from Namibia, that while its web is regularly destroyed by wind and sand it also adjusts the size of the trap according to the quantity of prey available, without changing the size of its retreat [205]. Riechert noted that Agelenopsis aperta webs tend to be larger in areas with limited prey, but there are no quantitative results to confirm this impression [206].

These results suggest an "evaluation" of prey availability and a comparison with information on the amount of prey captured previously, according to memory. Without excluding this possibility out of hand, the regulation of the attraction for silk by the state of satiety could reveal a much simpler mechanism than one involving highly complex cognitive processes. To compensate for daily reductions in the surface and volume of its web, or to expand its web, the spider must temporarily leave the web to reach neighbouring supports. But the attraction for silk determines the probability of the spider leaving its web, and therefore the rate of daily expansion. If this probability is high (due to a reduced attraction to silk), the extensions to the surface area and volume of the web may exceed daily destruction and lead to a net increase in the size of the trap. A low probability (in the case of well fed spiders, more attracted by silk), however, 
causes a reduction in the size of the web. The spider might as well settle for a state of balance between adjusting the size of the web with the availability of prey.

It has been shown in the field [190] that by providing extra food to some spiders and not others (the latter being limited to naturally captured prey) for four consecutive days, the web surface area of individuals fed artificially decreased slightly while those in the control group increased significantly. A similar result is found if volume rather than surface area is measured.

These results support the hypothesis of an adaptation where the size of webs is modified according to prey availability or satiety. When the amount of prey caught is enough to satiate the spider, it becomes more responsive to the attraction of silk. In a way, it becomes trapped by its own silken structures, which limits the ability of the spider to extend its web. A hungry spider lacking in prey, however, will be less responsive to its attraction for silk, and will have a greater likelihood of leaving the confines of its structure and further expanding the size of its web. The same mechanism, not involving complex cognitive processes, could explain why spiders abandon webs, as they need to search for a new construction site.

This simple model is certainly not perfect. It relies on quantitative stigmergy, but during construction there are also qualitative changes in behaviour that are not being taken into account. When the basic frame for the web is completed, the spider changes its behaviour by producing bundles of silk rather than mere threads. The draft shelter becomes replaced by a tubular retreat that is open at both ends. These initial structures generated on the basis of a quantitative stigmergy acquire, from a certain state of completion, further stimulating properties resulting in a new type of behaviour. But this model has successfully demonstrated that it is possible to obtain a coherent silken structure tailored to the individual and obeying certain architectural rules without the spider needing to have a "representation" of the overall structure. The spider's response to local information is sufficient.

\section{Silk as an Agent of Social Cohesion}

Of the approximately 40,000 species of spiders currently known, only about fifty are more or less social species $[29,47-49,166,207-216]$, yet biologists have focused on the causes for the emergence of sociality rather than the reasons for the individualistic nature of most species. The term social spider should be qualified. It consists in fact of those species that show parental behaviour, where the juveniles live for a limited time in the web developed by the parent and then form associations of individual webs (social but territorial), and species that collectively operate a common web. The latter group includes what is usually called the nonterritorial social spiders. They cooperate in the construction of the web, prey capture, the care of young, and colony defence.

Although web-spinning spiders show pronounced individualistic behaviour, coupled with an intolerance leading to cannibalism, there are occasions when they form associations with their individual webs, sheets, or networks.
These aggregations may depend on the structure of the environment when it offers a limited number of materials for attaching webs. The materials play the role of attractor. They also depend on the quantity of available prey [202] Nephila can form aggregations in environments rich in prey, where the webs are attached to each other. However, when prey becomes scarce, agonistic interactions increase and lead to the dispersal of individuals [217]. Some species of the genus Metepeira are gregarious or solitary according to the availability of prey [196].

One may wonder about the origin of these associations. Attracting spiders to areas rich in prey appears unlikely because this would suggest that they can remotely sense that an area will be more abundant in prey. It is more likely that spiders select suitable sites during their travels, and effectively become trapped by their rich environments, where they can remain grouped because of a temporary reduction of their intolerance. Tolerance between conspecifics can indeed be experimentally altered by manipulating diet [218-220]. But these groups can also be explained by an attraction to the webs of congeners or even of different species [221].

Some species show varying levels of maternal behaviour. Sometimes, the juveniles live for a period of time in the web of the mother, without gaining much care from her, but which nevertheless leads to energy savings in terms of silk production [222]. More often, the mother feeds her young with trophic eggs, by regurgitation or by abandoning her prey $[219,223-227]$. The mother can even offer its own body as a food source to the young [228-230]. Sometimes, juveniles will remain grouped into the subadult stage.

Communal structures begin when the juveniles construct their individual webs near each other and the mother. This is probably the origin of spider sociality in social territorial species, and while Uetz $[166,196]$ suggests that spiders of the genus Metepeira could come together as adults, this has not been proven. The communal web, therefore, consists of a large number of individual webs that are attached to each other. If the colony survives long enough, there may be an overlap of several generations [207, 231, 232]. But within these colonies, there remains a regular distribution of webs, modulated by genetic and environmental factors. The distances between individuals vary according to population size and prey availability. Juveniles from egg sacs collected in poor environments and bred in the laboratory under standard conditions show interindividual distances greater than those from egg sacs collected in rich environments. But even within a population, these distances vary with fluctuations in prey $[166,167,233]$. This regular distribution of webs is the result of agonistic interactions expressed mainly by an exchange of vibratory signals [232, 234, 235].

Individuals of Parawixia bistriata (a social territorial species) spend the day in a compact silky nest but at night move to their individual geometric webs which all hang from a vast network of common retaining threads. The construction of these webs is strictly individual, suggesting that the geometry of the web is an obstacle to cooperation. The capture of small prey is also individual, but occasionally large insects may attract many spiders onto the same web. They then cooperate to capture the prey $[236,237]$. 
These various social organizations offer both advantages and disadvantages. Merely staying temporarily in the irregular web built by the mother allows Holocnemus pluchei juveniles to save energy by reducing their need to produce silk [222]. The exploitation of existing webs promotes the survival of young [238]. Maternal behaviour also has a beneficial effect on juvenile development, particularly from the time the mother feeds her young [225, 227-230, 238].

The advantage of gregariousness among territorial social spiders seems less obvious since the capture of prey is essentially performed individually. However, in Metabus gravidus, building a web within a common network takes less time than if the spider was isolated $[48,231]$. The colonial structures also increase the catch rate per individual for Cyrtophora citricola and Metepeira spinipes [166, 196, 239-241]. The combination of individual webs can create a ricochet effect, where a prey that pierces one web because of its kinetic energy is likely to be stopped by a nearby web [242]. A ricochet effect has also been suggested in large communal colonies of Anelosimus eximius where "bystanders," spiders that surround a prey being subdued by "catchers," become catchers themselves if the prey temporarily breaks free and moves nearer to them [243].

One of the main benefits of nonterritorial social organization seems to be the ability to capture large prey, which would, otherwise, be uncontrollable for solitary spiders. Nentwig [244] has demonstrated that social spiders, however small, capture prey much larger than solitary species in tropical environments, increasing their range of available prey. In absolute terms, Anelosimus eximius captures more small prey $(70 \%)$ than large prey $(30 \%)$, but large prey provides $80 \%$ of the energy for the colony. Furthermore, the catch rate is $50 \%$ in small colonies compared to $76 \%$ in large colonies. These spiders are capable of capturing prey 700 times heavier than themselves [245]. The greater abundance of large prey in lowland tropical rainforest rather than at higher elevations helps to explain why Anelosimus eximius favours the lowlands [246]. The prey is also controlled more rapidly in Stegodyphus mimosarum if several individuals are involved in its capture [247]. If the colony becomes too large prey capture per capita falls due to the reduction of colony surface area compared to volume, triggering dispersal [248].

The society also provides an economy of silk. Frequent storms in the tropics regularly destroy webs. Reconstruction is less frequent among isolated than grouped individuals of Agelena consociata because of the relatively higher cost per individual in silk production and reduced social stimulation. Moreover, the expenditure of silk per spider decreases in large colonies, so that survival in small colonies is less than in large colonies $[249,250]$. This economy is also seen in the silk of Mallos gregalis [251]. The size of the web grows less rapidly than population size, which is offset by an increased efficiency in predation.

The larger web structures also provide some protective effects against weather and predators [51-53]. In Stegodyphus dumicola, social groups are less often attacked by ants, birds, and other species of spiders than isolated individuals [252]. The juveniles of Anelosimus eximius have a better chance of survival in large than small colonies [253].
Sociality also has its drawbacks. The chances of female Anelosimus eximius being able to reproduce decreases with increasing colony size [253]. There can also be competition between individuals, where some have better access to prey and reproduction $[51,254,255]$. These constraints in social life are also demonstrated by the fact that isolated individuals produce more eggs than individuals within a society [256258]. However, for Stegodyphus dumicola, the survival of the offspring that are produced increases [258], due in part to shared parenting [259].

All these phenomena are the consequence of group living, which itself is explained by the existence of a mechanism for group cohesion that reduces the possibility of dispersal by individuals. Unfortunately, researchers are more concerned about the possible external causes and consequences of these associations than in the mechanisms involved at the individual level. Group cohesion seems relatively loose amongst territorial social spiders, which allows some plasticity in the distribution of individuals, so that one sometimes finds spiders that have become isolated. The nonterritorial social spiders show more pronounced group cohesion, which has been stressed by many authors but rarely studied. The term interattraction as defined by Grasse [260,261], of attraction between individuals of the same species and sex, can be used as one of the criteria for defining nonterritorial social spiders [262]. Sociality in these spiders seems to be the general rule and the few isolated individuals sometimes found near web settlements are probably migrants seeking to establish a new colony. When a loose group of individuals of Agelena consociata or Anelosimus eximius are placed on a bush or in an empty chamber, they combine to form a new colony $[50,263]$.

Although there is an attraction produced by air-borne pheromones in Anelosimus eximius [190], silk, whose function is essential in bringing the sexes together also appears to be the main factor behind group cohesion. Those solitary spiders, whose webs sometimes show a distribution approaching the gregarious type, seem attracted to the silky structures of their congeners and even those of different species [221]. The aggregated geometric webs of Zygiella $x$-notata can be explained by an attraction for silk [264, 265]. This attraction may even occur between social and solitary species in the genus Stegodyphus [208, 209]. Different results have been obtained in Dictynides, a genus that also contains solitary and social species. Silk is attractive to social species, but not the solitary species [266]. For these species, individuals do not seem to distinguish between their own silk and that of congeners. There are exceptions as Portia labiata (Salticidae solitary species) discriminates between its silk and its congeners and even between the silk of known and unknown congeners [144, 145].

Regarding nonterritorial social species, laboratory experiments have shown that a silken substrate is attractive to Agelena consociata and leads to clustering by individuals [263]. This attraction depends on a pheromone associated with the silk in Diaea socialis, but individual responses to this stimulus varies depending on their physiological state. Adult females that are ready to lay eggs are repelled by the silk of conspecifics, which explains their emigration and the founding of new colonies [267]. An attraction for silk also 
overcomes repulsion between nestmates and nonnestmates in Anelosimus eximius, although colonies with both are less stable and less successful [268]. It seems that the attraction for silk is also modulated by the state of satiety in Agelena consociata and Stegodyphus sarasinorum as removing food will cause the spiders to leave their nest $[269,270]$. In this case, individual emigrants sometimes travel in groups, as is also the case with Anelosimus eximius [271].

The cohesion of the travelling group seems to be due to the threads of silk deposited by member spiders. In Anelosimus studiosus individuals tend to follow the threads of silk produced by congeners [210]. When spiders (Aebutina binotata) are about to leave their colony, they unleash threads that cling to the surrounding vegetation. An individual who progresses along one of these threads without being followed by its congeners returns to the colony, so that eventually only one of these potential routes is followed by the group [272].

The ability of social species to follow the trail of congeners of the same sex was based mainly upon field observations, without being proven experimentally. Early demonstrations were based upon T-maze experiments offering binary choice. Female Stegodyphus sarasinorum follows the tracks left by a congener of the same sex. This guidance requires the presence of a silken thread $[119,132,136]$. A similar technique has shown that in Anelosimus eximius individuals spend more time on a silky substrate woven by a congener than on a blank substrate. Also, spiders do not distinguish between their own silk and that of conspecifics, even if they were from different colonies [190, 273].

This attraction is governed by two factors, the density of the silk and the satiety of the individuals tested. In T-maze choice experiments, spiders spend more time on a sustrate covered with dense silk than on one covered with a thin layer of silk, a mechanism that could focus the movement of individuals towards the densest regions of the nest under natural conditions and restrict their travel to the periphery. As for the solitary spider Agelena labyrinthica, the attraction for silk is modulated by satiety. Starving spiders spend less time on a silky substrate than satiated individuals. Presumably, this variation in attraction allows adjustment of the size of the trap as in solitary species, and in social species the emigration of individuals or groups [190, 269, 271-273].

The role of silken threads in the cohesion of moving groups has been demonstrated experimentally and modelled [193, 274, 275]. A binary choice experiment in the field showed that the probability of a spider following a pre-existing thread is higher than for any other path. When released from a container connected to two equivalent branches of a bush by yarn in the shape of a Y, all spiders grouped upon one of the two branches. The theoretical modelshows that there is an optimal probability to follow a preexisting thread to maintain good cohesion. The attraction for silk therefore allows collective decision making (Figure 7) as is also the case in social caterpillars. A recent trace of silk within a choice of pathways becomes the route of priority $[5,6]$, which can be compared with the selection for chemical trails by ants [276]. Fernandez et al. [277] have modelled social spider attraction to silk in a sigmoidal way, where the

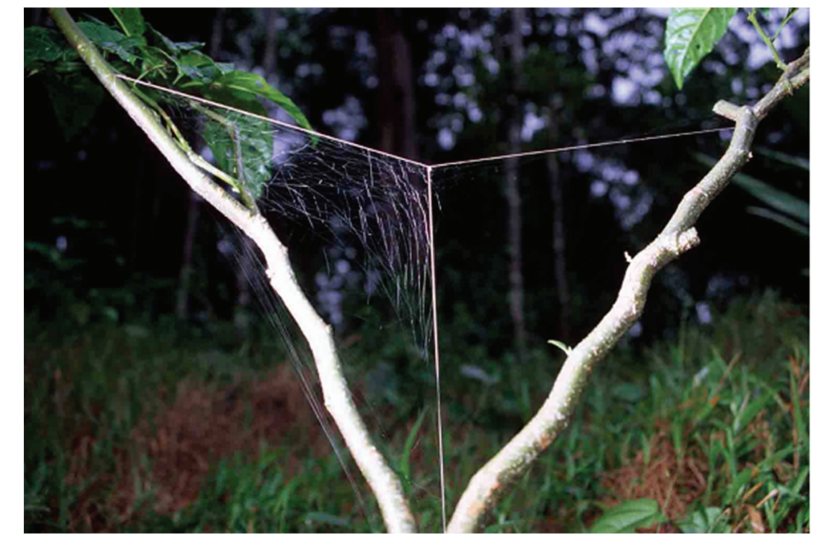

FIGURE 7: Given the choice between two branches of the shrub, spiders are attracted by threads to one of the branches (Anelosimus eximius; Photo Krafft).

number of founders in a colony has to exceed a critical value if settlement is to be successful and prevent dispersal.

The role of silk in social cohesion among spiders is further underlined by the fact that there are no social species without webs. Some authors have stressed the exceptions of Diaea socialis (Thomise) and Delena cancerides (Sparasside) where individuals live in a silky nest but outside are solitary hunters without webs $[211,212,267]$. In fact, these two examples only reinforce the idea that silk is essential for the social life of these spiders as sociality only occurs in the common nest.

\section{Silk as an Agent for Coordination and Cooperation in Social Construction}

By the 1940s, struck by the architecture of structures built by social insects and the many examples of cooperation during food harvesting, researchers saw these social insects as being fundamentally different to solitary insects. "The individual who belongs to a society differs in many respects to the solitary" [278]. The difference seemed so great that one wondered whether these social arthropods did not have a "global representation" of the structures they were to build or the task they were to realize (cooperative harvesting). This hypothesis was nevertheless difficult to accept because of the complexity and sometimes impressive size of the structures or complexities of actions compared to the apparently reduced cognitive abilities of the individuals involved. The theory of stigmergy developed by Grasse for termites [163, 279] lifted the veil on this mystery. Stigmergy is a mechanism where the structure created by an individual acquires stimulating properties that can control the behaviour of a congener by reducing its degrees of freedom. Although each step in the sequence of interactions is based on rigid stimulus/response reactions to local information only, this system enables a broader plasticity and the emergence of the phenomenon of self-organization, to produce complex and consistent structures, provided that the various acts are not organized into a hierarchical scheme of reactions. There 


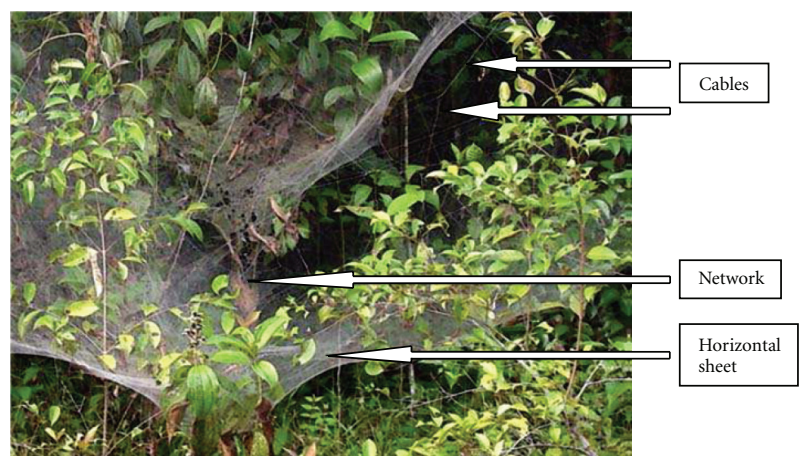

Figure 8: Portions of a web colony by Anelosimus eximius (Photo Krafft).

must be independence between each action. Widely adopted in recent years this theory has allowed us to understand the mechanisms of cooperation among ants, bees, wasps, and even some vertebrates [194, 276, 280-282].

All nonterritorial social spiders cooperate in building their irregular web trap, while the construction of geometric webs remains an individual activity amongst territorial social species. The architecture of the web can be a hindrance to cooperation and socialization, or it can promote these features $[47,55,68,119,232,235,283-286]$. As far as is known, there is only one nonterritorial social species from the orbweaving spiders (a species of Philoponella in the Uloboridae) that cooperates in the construction of webs and prey capture. But the geometry of their webs has suffered. Their traps look more like the irregular structures of social species allowing nonterritorial and cooperative behaviour [287].

The traps constructed by Anelosimus eximius are impressive. They often reach a volume of $100 \mathrm{~m}^{3}$. Although described as irregular, these traps obey certain architectural rules. The colony consists of one or several closely interconnected components each comprising a horizontal sheet, or hammock, above which is a silky three-dimensional network (Figure 8). Spiders are divided into groups under leaves embedded in the network [50,271]. This structure is quite similar to that woven by Agelena consociata [49] and Agelena labyrinthica [190], with the difference being that the horizontal sheet does not rest upon a dense layer of vegetation but hangs below the plant material. It is built on the border between a dense medium above, and an open area underneath, which does not fundamentally change the problem relative to A. labyrinthica. But despite these rules, the overall shape of the structure varies considerably from one colony to another depending on the plant material utilised.

It is impossible to conceive that a $6 \mathrm{~mm}$ long spider has a representation of a three-dimensional structure tens of $\mathrm{m}^{3}$ in size, along with the distribution of fixing points upon a range of substrates. Yet few studies address this aspect of social behaviour. Tietjen is probably the first to have considered a process of self-organization for the construction of the web by Mallos gregalis [288]. He noted that if we let spiders loose in an enclosure, the activity of individuals seems chaotic until the appearance of the first draft of a structure. The spiders then focus their constructive activity, which enables the rapid development of a communal nest. Aviles also noted the synchronization of construction activities by Tapinillus sp. [289]. It seems that during an initial period of inactivity, the mobilization of one individual can lead to the mobilization of others.

Yet the difference between solitary and social spiders seems so great that one is inclined to devise specific mechanisms of cooperation for the latter. However, the change from a solitary to social status has been made at least thirteen times by independent lineages $[47,290]$. Despite the scarcity of social species, this transition has been frequent. This raises the problem of the ethological changes that would be needed for the emergence of cooperation during construction. Either these changes are important and numerous, which seems at odds with the frequency of the change amongst the lineages, or these changes are minimal, which seems difficult to accept because of the dramatic differences between the architecture of solitary and social structures.

However, the mechanisms governing the construction of the web does not seem fundamentally different between solitary and social species. If we drop Anelosimus eximius onto a small bush and leave the spider time to build the first draft of its web before removing it from the area, a second individual will expand and complete the construction rather than start anew. The first initial web built by an individual is able to control the behaviour of a fellow builder in accordance with the principles stigmergy (Figure 9). Furthermore, spiders are able to repair a hole in the hammock without changing its architecture, which shows independence between the various acts relating to construction, the essential principle of stigmergy [190].

This raises the question of whether social spiders simply would not use the mechanisms highlighted in solitary spiders (see web building by Agelena labyrinthica). However, in Anelosimus eximius, silk is attractive to congeners, which appears to be a characteristic of social species. But is it really a social characteristic? Agelena labyrinthica is attracted to its own silk as much as the silk of its congeners [190].

This is also the case for Steatoda triangulosa (Theridiidae) and Tegenaria domestica (Agelenidae), two solitary spiders that belong to families that also contain social species. It may therefore be hypothesized that solitary spiders have all the ethological mechanisms necessary for cooperation except the mutual tolerance that would allow them to work together on a common web.

This hypothesis is confirmed by the fact that it is possible to obtain a complete and fully functional web from Agelena labyrinthica when a succession of three individuals is placed separately on site. Each new spider continues their part of the work according to the structures already in place. The self-stigmergy demonstrated in this spider thus gives way to social stigmergy. This suggests that spiders can be unaware yet perfectly able to cooperate in the construction of a web.

Since this assumption is impossible to verify on biological material, it is necessary to use modelling to determine if it is at least sufficient to explain cooperation [190, 291, 292]. If, on the basis of behavioural rules identified in Agelena labyrinthica, we drop multiple virtual spiders in the virtual 


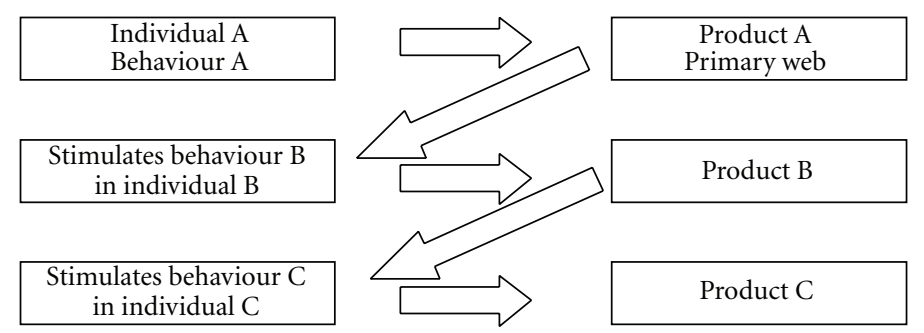

Figure 9: The stigmergy process. The behaviour of an individual is driven by the product of the behaviours of its congeners. Notice the difference with Figure 5.

environment, they build a common web provided that the probability of attraction for silk is adequate. If no attraction, the structure produced fills the entire space. With an average attraction, spiders gather gradually, grouped within a common structure. If another rule were added to the model that limits the life of a thread, the result would probably be even clearer because it would erase the first threads woven before the individuals began grouping. However, individual webs result if the attraction for silk is too strong, with each spider remaining trapped on its own structure.

As for the Agelena labyrinthica model, the size of the common web produced is inversely proportional to the attraction of silk. The validity of this model is further strengthened by the fact that, as with social spiders, the size of the structure produced grows less rapidly than population size. Both effects emerge as nonprogrammed features in the model.

None of the rules of this model involve direct interaction between individuals. These virtual spiders are unaware of any plan and ignore each other (i.e., no attraction, no aggression, and no signals between individuals), but simply take account of local information related to the presence of silk, whatever its origin. This suggests that cooperation during construction in social spiders is related to stigmergy based on ethological programs already present in solitary species, where the emergence of communal webs arises from a process of selforganization where individuals tolerate or can more simply ignore each other.

\section{Silk as an Agent for Coordination and Cooperation during Prey Capture}

Cooperation during prey capture is a feature of social spiders, at least in regard to nonterritorial social species $[49,247$, $255,272,289,293,294]$. Indeed, territorial social species that build sets of individual geometric webs do not cooperate in the control of prey $[232,234,235]$, even though indirectly, these associations increase the catch rate per individual [241, 242]. An exception is that when individuals of Parawixia bistriata can access a web nearby, they will move in and help when the prey is large $[236,237]$. The geometry of the web can be a hindrance to cooperation $[47,232,235,284]$, which is confirmed by the fact that the only species in the orbweaving group that communally captures prey, Philoponella sp., became a nonterritorial social species that constructs irregular webs similar to that of Anelosimus eximius [287], while Philoponella republicana, which uses geometric webs, is a social territorial species.

The idea that silk is an agent of cooperation during predation is also reinforced by the example of certain social or subsocial species that do not spin webs. The Thomisid spider Diaea socialis builds a nest formed by assembling leaves together into a silken package. The young remain in this structure until adulthood, but adult gravid females leave [267]. To catch prey individuals leave the nest and hunt independently without a trap but share the prey brought back to the colony [211]. The sparassid spider Delena cancerides makes the same kind of structure, except that the nest may contain several females [212]. These authors mention that under artificial laboratory conditions, several individuals placed in a common enclosure can combine their efforts to capture prey. But there are no observations in nature to confirm this act, which should involve a coordinated movement of individuals through specific signals in a process similar to that of ants.

These findings suggest that the lack of a common trap prevents any form of cooperation during prey capture, or more precisely that it is the presence of a common trap that enables cooperation. What could be the mechanism? The descriptions of cooperative behaviour during predation among nonterritorial social spiders are relatively rare and scarce in detail. Bradoo claimed to have observed in Stegodyphus sarasinorum that the first individuals in contact with prey vibrated threads to emit recruitment signals [269]. But it is also likely that behaviours manifested by any spider facing prey only adds to the vibrations produced by the victim, which in turn facilitates its location by congeners. The latter seems more likely, as the original observations have not been confirmed [247]. While it is not certain that specific recruitment signals occur, simple cooperation also allows the efficient capture of large prey [244, 245].

There is, however, a curious behaviour in Anelosimus eximius which could lead to the recruitment of individuals towards prey. The movements of spiders towards prey are interspersed with short stops, which is probably to aid location and reorientation by individuals towards the prey as is the case with solitary species of Agelenides. A synchronization of these stops produces characteristic vibrational phenomena that can lead other individuals to the catch. During the 
stationary phase, it is sufficient that when one of the participants moves that the others will follow, and these synchronized movements persist for several seconds after the disappearance of the prey [295]. But the role of these phenomena as a vibratory signal for recruitment is not demonstrated.

Prey vibrations were found to play a major role in the recruitment of spiders, where buzzing prey attracted more spiders than nonbuzzing prey $[243,296]$. Prey length rather than prey mass also increased the number of spiders involved in prey transportation, as longer prey simply provided more sites upon which spiders can grip or pull [296]. Response to these simple cues precludes the need for the specific recruitment signals found in some social insects such as ants. Spiders provide an example of self-organising processes in group predation, where the movement of one spider engaged in group transport is likely to modify the stimuli perceived by the other group members (such as vibration produced, or indirectly, available sites on the prey), possibly producing in turn recruitment or departure of individuals [296].

Without a priori excluding the intervention of recruitment signals, it is possible to explain cooperation in social spiders during predation by referring to simple mechanisms based on stigmergy processes that favour silk. In Anelosimus eximius, spiders exhibit several types of behaviour when capturing prey. They throw sticky silk onto the victim to hinder it, followed by projections of dry silk to complete the immobilisation. Their bites paralyse the victim. For transportation towards their shelter, spiders fix threads to hoist the prey while cutting the threads that retard its progression [297]. By cutting these sequences of predation into four phases of equal duration, one finds that there is a sequential organization to the manifestation of these acts [298].

In phase 1 , spiders project mainly sticky silk. Phase 2 is marked by projections of dry silk and biting. Bites become more important during phase 3 and transportation appears in phase 4 [298]. The partial recovery of these actions over time can be explained by the simultaneous intervention of several individuals. Despite appearances, there is not a rigid sequential organization of these various acts, nor the successive intervention of specialized individuals. Each spider is indeed able to demonstrate each of these acts if alone with the prey. However, within a group, the spider adjusts its behaviour to the situation encountered in terms of local information relevant to the state of the prey.

This independence of action, essential to the manifestation of stigmergy, allows the group to adjust its behaviour to the state of the prey. If we offer a killed prey to spiders and attract them using a set of short vibrations, they immediately manifest into the act of transportation. When applying a second set of vibrations (V2) spiders will project sticky silk and bite as in early capture. After stopping the vibrations spiders again engage in transportation.

The results of a theoretical model $[298,299]$ in which each spider would act independently of others and simply adjust its behaviour to the state of the prey resulting from previous actions, show a similar sequential organization of the different behaviours. As we know in solitary webspinning spiders, predatory behaviour is mainly driven by the vibrations produced by prey. This adjustment could be a variation of probabilities that manifest a particular act in function according to the force with which the prey struggles. Indeed, during capture, the prey is exhausted and gradually moves less and less.

\section{Conclusion: Silk Architecture and Its Factor in Socialization}

The webs of spiders have caught the imagination. Interest at first centres upon the geometric webs, but then we also find that "irregular" webs obey specific architectural rules. It was then a simple step to imagine that the spider had a plan or instinct of how to build its web in its "head." The results mentioned above can, however, reject this hypothesis which is hardly compatible with the cognitive abilities of spiders. Processes of autostigmergy help explain the architecture of webs using simple stimulus/response reactions to local information without necessarily involving reference to a representation of the overall situation. The spider, guided by the configuration of the environment, sets up the first silky structure and thereafter takes its guidance for the construction process according to stigmergy. It is likely that the same is true for geometric webs, although responses to various stimuli are not all identified. These responses, certainly different from one species to another, could explain the differences in architecture. For example, slit sensilla on the legs of spiders are like biological strain gauges [300], and their architecture may suggest an optimal level of tension in the webs of spiders, which in turn would suggest to the spider when to fix or join its web. It is not the spider that "decided" to build a web that would obey certain architectural features, but the silky structure itself that controls the behaviour of the manufacturer according to rules governing its stimulus/response reactions. The silk itself is the architect in the construction of the web.

The first authors who studied nonterritorial social spiders stressed the three behavioural characteristics that distinguish them from solitary species, mutual tolerance, interattraction, and cooperation $[49,257,262,263]$. This concept of sociality in spiders has been widely adopted since $[47,48$, $213,214]$. Based on the observation of differences between the most exemplary solitary and social species, without taking into account the ethological mechanisms behind these features, a disadvantage was the apparent widening of the gap between these two modes of life, and suggestions that the transition from solitary to social required the development of several behavioural innovations. However, despite the scarcity of social species, this transition has occurred in independent lineages at least thirteen times [47, 290], making this hypothesis implausible.

The existence of several species showing maternal behaviour more or less developed in families that also contain social species, such as Erésides [52, 209, 301, 302], Théridionides [223, 262], the Dictynides [213, 272], and Agélénides $[227,303]$, suggests a gradual evolution of sociality from the family group [215, 284, 304]. However, there are genera such as Agelena for example, that contain social species (Agelena consociata and Agelena republicana) but no maternal species. Conversely, many genera contain maternal species but no 
social species. We can, therefore, assume abrupt transitions, which can only be explained if socialization requires only minor ethological modifications.

The ethological study of the mechanisms that govern the functioning of juvenile groups and parent/juvenile groups can answer these questions $[219,226,305]$. The young of all species of spiders stay grouped for a few days after emergence from the egg sac. They often weave a common three-dimensional web. The construction of this structure has never been studied, even though it is the result of cooperation between individuals. After their emergence from the egg sac, young spiders therefore have the potential required to cooperate in building a common network. Only after their dispersal do the young orb-weaving spiders build their individual geometric webs. The mere fact that they remain together also implies the involvement of a mechanism for group cohesion. Finally, perfectly capable of eating prey they are offered, cannibalism is very rare. The three characteristics of social spiders are present at birth, so fleeting, in all spiders, but disappear with the dispersal of young.

The disappearance of ethological mechanisms responsible for tolerance, group cohesion and cooperation is not strictly programmed in all species. Juvenile Coelotes terrestris (Amaurobiidae) normally stay in their mother's web for a month and then disperse to weave individual irregular webs. During this period, they are fed by the mother and can even devour their own mother if intake is insufficient [227, 303]. The interattraction and tolerance between juveniles still persists if we remove them experimentally from the nest of the mother [306]. Siblings of Amaurobius ferox will remain together for several weeks in the natal nest after the death of the mother [307]. The factor responsible for the cohesion of the group was not identified. However, we can imagine that this is an attraction for silk. In Coelotes terrestris, the gregarious phase can be experimentally extended to several weeks if the mother is endowed with abundant prey. The young grow faster but disperse later, indicating that the disappearance of the tendency to group and tolerate congeners is not related to a genetically programmed age [220]. If we prevent the dispersal of juveniles by keeping them in an enclosed space and providing abundant food, they grow to adulthood, reproduce, and build a structure very similar to the common silky webs of the social spider Agelena consociata, thus forming an artificial society [218]. They appear to develop cooperation in construction. Cannibalism is extremely limited, giving evidence to the persistence of tolerance, and sometimes two or three individuals even participate in capturing prey. The plasticity of tolerance opened the path to socialization. Presumably, under favourable ecological conditions and an abundance of prey there was persistence of tolerance and the emergence of social structures and behaviours.

There is a point to remember however. All species that exhibit maternal behaviour belong to groups that spin irregular webs, or at least build a silky shelter. The only exception is Lycosides vagabondes which carries its young on its back for several days without feeding them. No cases of maternal behaviour have been reported in orb-weaving spiders. We can, therefore, consider that the presence of a nongeometric web was essential to the emergence of maternal behaviour. All social spiders belong to species that spin webs or at least settle in a common silky shelter. Silk seems to be a key factor in the socialization of spiders.

The comparison between social orb-weaving spiders that are territorial and nonterritorial species also deserves consideration. The only form of cooperation in territorial social spiders, apart from occasional cooperation in the capture of large prey by Eriophora bistriata [236], is the building of a common framework for fixing the threads of their individual geometric webs. That is to say that the part built in common corresponds to an irregular network, and does not correspond to the geometric webs that are then built on a strictly individual basis. Moreover, the only orb-weaving spider that displays cooperation in the construction of webs and the capture of prey is a species from the genus Philoponella that weaves irregularly shaped webs [287]. We can therefore consider that the architecture of the geometric webs of orbweaving spiders has been an obstacle to perfect socialization, both in regards to web construction and collective predation.

But the persistence of tolerance and cohesion in a group does not explain the coordination of individual activities or cooperation. Should there be specific coordination mechanisms as in social insects? The results concerning cooperation in construction and collective prey capture suggests not. The silken web directly provides spiders with the information they need. The structures in place drive the building behaviour of individuals, and information transmitted by vibrations in threads allows the coordination of their predatory activities. Cooperation is therefore a product that emerges from the operation of a common web and requires no modification to the ethological programming of solitary spiders. Even in solitary spiders there is an attraction for silk from congeners that would potentially allow group cohesion and also cooperative social organization if tolerance between individuals persisted. As no specific form of communication is fundamentally necessary, even spiders that ignore each other but exploit a communal silky structure could in effect cooperate. It is therefore possible to imagine an abrupt change of status from solitary to social living among spiders [308]. This suggests that silk is the main determinant of cooperation in social spiders and thus their socialization, as may also be true for caterpillars, mites, and social Embioptera. Some authors have argued the contrary based on individual cases such as Diaea socialis [211] and Delena cancerides [212]. But these spiders do not use webs when hunting, live in a communal retirement, and capture prey individually outside, which only confirms the importance of a common irregular web to elicit social cooperation.

Unlike social insects that have developed communication signals that are more or less complex and different to those of solitary insects, spiders are merely exploiting the social aspects of a pre-existing material found in solitary species, silk. Ants became social well before "learning" to use the silk of their larvae, so developed a complex chemical language, while spiders have become social because of their use of silk. "If one can consider that "the road to insect sociality is paved with pheromones" [309], one must grant that the society of the spider hangs by a thread" [119]. 


\section{References}

[1] C. L. Craig, "Evolution of arthropod silks," Annual Review of Entomology, vol. 42, pp. 231-267, 1997.

[2] P. A. Selden, "Orb-web weaving spiders in the early Cretaceous," Nature, vol. 340, no. 6236, pp. 711-713, 1989.

[3] W. A. Shear, J. M. Palmer, J. A. Coddington, and P. M. Bonamo, "A Devonian spinneret: early evidence of spiders and silk use," Science, vol. 246, no. 4929, pp. 479-481, 1989.

[4] V. S. Haritos, A. Niranjane, S. Weisman, H. E. Trueman, A. Sriskantha, and T. D. Sutherland, "Harnessing disorder: onychophorans use highly unstructured proteins, not silks, for prey capture," Proceedings of the Royal Society B, vol. 277, no. 1698, pp. 3255-3263, 2010.

[5] T. D. Fitzgerald, The Tent-Caterpillars, Cornell University Press, Ithaca, NY, USA, 1995.

[6] T. D. Fitzgerald and J. T. Costa, "Collective behavior in social caterpillars," in Information Processing in Social Insects, C. Detrain, J. L. Deneubourg, and J. M. Pasteels, Eds., pp. 379400, Birkhäuser, Basel, Switzerland, 1990.

[7] G. A. R. Melo, "Silk glands in adult sphecid wasps (Hymenoptera, Sphecidae, Pemphredoninae)," Journal of Hymenoptera Research, vol. 6, pp. 1-9, 1997.

[8] B. Hölldobler and E. O. Wilson, "Weaver ants," Scientific American, vol. 237, pp. 146-154, 1997.

[9] B. Holldobler and E. O. Wilson, "The evolution of communal nest-weaving in ants," American Scientist, vol. 71, no. 5, pp. 490-499, 1983.

[10] B. Hölldobler and E. O. Wilson, The Ants, Belknap Press, Cambridge, Mass, USA, 1990.

[11] U. Maschwitz, K. Dumpert, T. Botz, and W. Rohe, "A silk-nest weaving Dolichoderine ant in a Malayan rain forest," Insectes Sociaux, vol. 38, no. 3, pp. 307-316, 1991.

[12] S. Siri and S. Maensiri, "Alternative biomaterials: natural, non-woven, fibroin-based silk nanofibers of weaver ants (Oecophylla smaragdina)," International Journal of Biological Macromolecules, vol. 46, no. 5, pp. 529-534, 2010.

[13] F. Schremmer, "Die nahezu unbekannte neotropische Weberameise Camponotus (Myrmobrachys) senex (Hymenoptera, Formicidae)," Entomologia Generalis, vol. 5, pp. 363-378, 1979.

[14] B. L. Fisher and H. G. Robertson, "Silk production by adult workers of the ant Melissotarsus emeryi (Hymenoptera, Formicidae) in South African fynbos," Insectes Sociaux, vol. 46, no. 1, pp. 78-83, 1999.

[15] H. Wundtm, "Schnabel und Köcherfliegen," in Grimeks Tierleben, Enzyklopädie des Tierreiches. II, Insekten, pp. 300-305, Kindler, Zürich, Switzerland, 1969.

[16] E. Kullmann, "Netze in Natur und Technik," in Proceedings of the 2th Interdisziplinäres Kollokium der Reihe, Biologie und Bauen, Universität Stuttgart, 1975.

[17] A. Le Doux, "Biologie et comportement de l'embioptère Monotylota ramburi Rims. Kors," Annales des Sciences Naturelles, vol. 20, pp. 515-532, 1958.

[18] J. C. Choe, "Communal nesting and subsociality in a webspinner, Anisembia texana (Insecta: Embiidina: Anisembiidae)," Animal Behaviour, vol. 47, no. 4, pp. 971-973, 1994.

[19] J. S. Edgerly, "Life beneath silk walls: a review of the primitively social Embiida," in The Evolution of Social Behavior in Insects and Arachnids, J. C. Choe and B. J. Crespi, Eds., pp. 14-25, Cambridge University Press, Cambridge, UK, 1997.

[20] J. S. Edgerly, S. M. Shenoy, and V. G. Werner, "Relating the cost of spinning silk to the tendency to share it for three embiids with different lifestyles (Order Embiidina: Clothodidae, Notoligotomidae, and Australembiidae)," Environmental Entomology, vol. 35, no. 2, pp. 448-457, 2006.

[21] B. J. Crespi and L. A. Mound, "Ecology and evolution of social behavior among Australian gall thrips and their allies," in The Evolution of Social Behavior in Insects and Arachnids, J. C. Choe and B. J. Crespi, Eds., pp. 166-180, Cambridge University Press, Cambridge, UK, 1997.

[22] E. L. Mockford, "Life history studies on some Florida insects of the genus Archipsocus (Psocoptera)," Bulletin of the Florida State Museum, Biological Sciences, vol. 1, pp. 253-274, 1957.

[23] J. Kovoor, "Comparative structure and histochemistry of silkproducing organs in Arachnids," in Ecophysiology of Spiders, W. Nentwig, Ed., pp. 160-186, Springer, Berlin, Germany, 1987.

[24] Y. Saito, "Biparental defence in a spider mite (Acari: Tetranychidae) infesting Sasa bamboo," Behavioral Ecology and Sociobiology, vol. 18, no. 5, pp. 377-386, 1986.

[25] Y. Saito, "Sociality and kin selection in Acari," in The Evolution of Social Behavior in Insects and Arachnids, J. Choe and B. J. Crepsi, Eds., pp. 443-457, Cambridge University Press, Cambridge, UK, 1997.

[26] G. J. L. Goff, A. C. Mailleux, C. Detrain, J. L. Deneubourg, G. Clotuche, and T. Hance, "Group effect on fertility, survival and silk production in the web spinner Tetranychus urticae (acari: Tetranychidae) during colony foundation," Behaviour, vol. 147, no. 9, pp. 1169-1184, 2010.

[27] P. Weygoldt, "Spermatophore web formation in a pseudoscorpion," Science, vol. 153, no. 3744, pp. 1647-1649, 1966.

[28] P. Weygoldt, The Biology of Pseudoscorpions, Harvard University Press, Cambridge, Mass, USA, 1969.

[29] L. Berland, Les Arachnides, Paul Lechevalier \& Fils, Paris, France, 1932.

[30] W. Nentwig and S. Heimer, "Ecological aspects of spider webs," in Ecophysiology of Spiders, W. Nentwig, Ed., pp. 211225, Springer, Berlin, Germany, 1987.

[31] B. Cutler, "Methods for preparation of cribellate silk fibrils," Microscopy and Microanalysis, pp. 1076-1077, 1995.

[32] W. G. Eberhard and F. Pereira, "Ultrastructure of cribellate silk of nine species in eight families and possible taxonomic implications (Araneae: Amaurobiidae, Deinopidae, Desidae, Dictynidae, Filistatidae, Hypochilidae, Stiphidiide, Tengellidae)," Journal of Arachnology, vol. 21, pp. 161-174, 1993.

[33] J. M. Gosline, M. E. D, and M. W. Denny, "The structure and properties of spider silk," Endeavour, vol. 10, no. 1, pp. 37-43, 1986.

[34] S. F. Y. Li, A. J. McGhie, and S. L. Tang, "New internal structure of spider dragline silk revealed by atomic force microscopy," Biophysical Journal, vol. 66, no. 4, pp. 1209-1212, 1994.

[35] D. G. Stubbs, E. K. Tillinghast, M. A. Townley, and N. A. Cherim, "Fibrous composite structure in a spider silk," Naturwissenschaften, vol. 79, no. 5, pp. 231-234, 1992.

[36] M. Xu and R. V. Lewis, "Structure of a protein superfiber: spider dragline silk," Proceedings of the National Academy of Sciences of the United States of America, vol. 87, no. 18, pp. 7120-7124, 1990.

[37] C. Boutry and T. A. Blackledge, "Biomechanical variation of silk links spinning plasticity to spider web function," Zoology, vol. 112, no. 6, pp. 451-460, 2009.

[38] M. Edwin DeMont, C. J. McConnell, and J. B. Carmichael, "Measuring the physical properties of silk from a spider's web," American Biology Teacher, vol. 58, no. 8, pp. 475-477, 1996. 
[39] M. A. Garrido, M. Elices, C. Viney, and J. Pérez-Rigueiro, "The variability and interdependence of spider drag line tensile properties," Polymer, vol. 43, no. 16, pp. 4495-4502, 2002.

[40] J. J. Gilman, "Strength of spider silk," Science, vol. 272, no. 5258, p. 17, 1996.

[41] B. Madsen, Z. Z. Shao, and F. Vollrath, "Variability in the mechanical properties of spider silks on three levels: interspecific, intraspecific and intraindividual," International Journal of Biological Macromolecules, vol. 24, no. 2-3, pp. 301-306, 1999.

[42] P. Schneider, "Elastic properties of the viscid silk of orbweaving spiders (Araneidae)," Naturwissenschaften, vol. 82, no. 3, pp. 144-145, 1995.

[43] S. L. Stauffer, S. L. Coguill, and R. V. Lewis, "Comparison of physical properties of three silks from Nephila clavipes and Araneus gemmoides," Journal of Arachnology, vol. 22, pp. 511, 1994.

[44] E. K. Tillinghast and M. Townley, "Chemistry, physical properties, and synthesis of Araneidae orb webs," in Ecophysiology of Spiders, W. Nentwig, Ed., pp. 203-210, Springer, Berlin, Germany, 1987.

[45] F. Vollrath, "Strength and structure of spiders' silks," Reviews in Molecular Biotechnology, vol. 74, no. 2, pp. 67-83, 2000.

[46] R. W. Work, "Viscoelastic behaviour and wet supercontraction of major ampullate silk fibres of certain orb-webbuilding spiders (Araneae)," Journal of Experimental Biology, vol. 118, pp. 379-404, 1985.

[47] L. Aviles, "Causes and consequences of cooperation and permanent-sociality in spiders," in The Evolution of Social Behavior in Insects and Arachnids, J. C. Choe and B. J. Crespi, Eds., pp. 476-498, Cambridge University Press, Cambridge, UK, 1997.

[48] R. E. Buskirk, "Sociality in Arachnida," in Social Insects, Vol. 2, H. R. Hermann, Ed., pp. 281-367, Academic Press, New York, NY, USA, 1981.

[49] B. Krafft, "Contribution à la biologie et à l'éthologie d'Agelena consociata Denis (araignée sociale du Gabon) I," Biologia Gabonica, vol. 3, pp. 197-301, 1970.

[50] R. Leborgne, B. Krafft, and A. Pasquet, "Experimental study of foundation and development of Anelosimus eximius colonies in the tropical forest of French Guiana," Insectes Sociaux, vol. 41, no. 2, pp. 179-189, 1994.

[51] P. I. Ward, "Prey availability increases less quickly than nest size in the social spider Stegodyphus mimosarum," Behaviour, vol. 97, no. 3-4, pp. 213-225, 1986.

[52] W. Wickler and U. Seibt, "Pedogenetic sociogenesis via the 'sibling-route' and some consequences for Stegodyphus spiders," Ethology, vol. 95, pp. 1-18, 1993.

[53] U. Seibt and W. Wickler, "The protective function of the compact silk nest of social Stegodyphus spiders (Araneae, Eresidae)," Oecologia, vol. 82, no. 3, pp. 317-321, 1990.

[54] W. Blein, K. Fauria, and Y. Henaut, "How does the tarantula Lasiodora parahybana Mello-Leitao, 1917 (Araneae, Theraphosidae) detect its prey?" Revue Suisse de Zoologie, Hors Série, pp. 71-78, 1996.

[55] J. W. Burgess and P. N. Witt, "Spider webs: design and engineering," Interdisciplinary Science Reviews, vol. 1, pp. 322335, 1976.

[56] E. J. Kullmann, "The convergent development of orbwebs in cribellate and ecribellate spiders," Integrative and Comparative Biology, vol. 12, no. 3, pp. 395-405, 1972.

[57] S. E. A. Hallas and R. R. Jackson, "Prey-holding abilities of the nests and webs of jumping spiders ( Araneae, Salticidae)," Journal of Natural History, vol. 20, no. 4, pp. 881-894, 1986.
[58] H. M. Peters, "Fine structure and function of capture threads," in Ecophysiology of Spiders, W. Nentwig, Ed., pp. 187-202, Springer, Berlin, Germany, 1987.

[59] T. Strohmenger and W. Nentwig, "Adhesive and trapping properties of silk from different spider species," Zoologischer Anzeiger, vol. 218, pp. 9-16, 1987.

[60] S. E. Riechert, "Energy-based territoriality in populations of the desert spider Agelenopsis aperta," Symposium of the Zoological Society of London, vol. 42, pp. 211-222, 1978.

[61] S. E. Riechert, "Games spiders play: behavioral variability in territorial disputes," Behavioral Ecology and Sociobiology, vol. 3, no. 2, pp. 135-162, 1978.

[62] K. Tanaka, "Energetic cost of web construction and its effect on web relocation in the web-building spider Agelena limbata," Oecologia, vol. 81, no. 4, pp. 459-464, 1989.

[63] D. B. Peakall and P. N. Witt, "The energy budget of an ORB web building spider," Comparative Biochemistry and Physiology, vol. 54, no. 2, pp. 187-190, 1976.

[64] K. N. Prestwich, "The energetics of web building in spiders," Comparative Biochemistry and Physiology, vol. 57, no. 3, pp. 321-326, 1977.

[65] K. Chmiel, M. E. Herberstein, and M. A. Elgar, "Web damage and feeding experience influence web site tenacity in the orbweb spider Argiope keyserlingi karsch," Animal Behaviour, vol. 60 , no. 6, pp. 821-826, 2000.

[66] W. G. Eberhard, "Effects of gravity on temporary spiral construction by Leucauge mariana (Araneae: Araneidae)," Journal of Ethology, vol. 5, no. 1, pp. 29-36, 1987.

[67] W. M. Masters, "Vibrations in the orbwebs of Nuctenea sclopetaria (Araneidae)-I. Transmission through the web," Behavioral Ecology and Sociobiology, vol. 15, no. 3, pp. 207215, 1984.

[68] P. N. Witt, "The web as a means of communication," Biosciences Communications, vol. 1, pp. 7-23, 1975.

[69] W. M. Masters and H. Markl, "Vibration signal transmission in spider orb webs," Science, vol. 213, no. 4505, pp. 363-365, 1981.

[70] D. K. Hoffmaster, "Responses of the spider Argiope aurantia to low frequency phasic and continuous vibrations," Animal Behaviour, vol. 30, no. 1, pp. 123-127, 1982.

[71] W. Holden, "Behavioral evidence of chemoreception on the legs of the spider Araneus diadematus," Journal of Arachnology, vol. 3, pp. 207-210, 1977.

[72] D. A. Parry, "The signal generated by an insect in a spider's web," Journal of Experimental Biology, vol. 43, no. 1, pp. 185192, 1965.

[73] R. B. Suter, "Cyclosa turbinata (Araneae, Araneidae): prey discrimination via web-borne vibrations," Behavioral Ecology and Sociobiology, vol. 3, no. 3, pp. 283-296, 1978.

[74] C. Viera, "Discrimination by Metepeira seditiosa (Keyserling) (Araneae, Araneidae) of two prey organisms under experimental conditions," Journal of Arachnology, vol. 23, pp. 1724, 1995.

[75] D. Klärner and F. G. Barth, "Vibratory signals and prey capture in orb-weaving spiders (Zygiella x-notata, Nephila clavipes; Araneidae)," Journal of Comparative Physiology A, vol. 148, no. 4, pp. 445-455, 1982.

[76] F. G. Barth, "Slit sense organs: "strain gauges" in the Arachnid exoskeleton," Symposium of the Zoological Society of London, vol. 42, pp. 439-448, 1978.

[77] F. G. Barth, "Spiders and vibratory signals: sensory reception and behavioral significance," in Spider Communication: Mechanisms and Ecological Significance, P. N. Witt and J. S. 
Rovner, Eds., pp. 67-122, Princeton University Press, Princeton, NJ, USA, 1982.

[78] F. G. Barth and J. Bohnenberger, "Lyriform slit sense organ: thresholds and stimulus amplitude ranges in a multi-unit mechanoreceptor," Journal of Comparative Physiology A, vol. 125, no. 1, pp. 37-43, 1978.

[79] J. Bohnenberger, "The transfer characteristics of a lyriform slit sense organ," Symposium of the Zoological Society of London, vol. 42, pp. 449-455, 1978.

[80] R. Hergenröder and F. G. Barth, "Vibratory signals and spider behavior: how do the sensory inputs from the eight legs interact in orientation?" Journal of Comparative Physiology A, vol. 152, no. 3, pp. 361-371, 1983.

[81] P. Görner and B. Claas, "The influence of the web on the directional orientation in the funnel-web spider Agelena labyrinthica Clerck," Verhandlungen der Deutschen Zoologische Gesellschaft, vol. 72, p. 316, 1979.

[82] R. B. Suter, "Web tension and gravity as cues in spider orientation," Behavioral Ecology and Sociobiology, vol. 16, no. 1, pp. 31-36, 1984

[83] S. A. Naftilan, "Transmission of vibrations in funnel and sheet spider webs," International Journal of Biological Macromolecules, vol. 24, no. 2-3, pp. 289-293, 1999.

[84] T. A. Blackledge, "Stabilimentum variation and foraging success in Argiope aurantia and Argiope trifasciata (Araneae: Araneidae)," Journal of Zoology, vol. 246, no. 1, pp. 21-27, 1998.

[85] K. Nakata, "Spiders use airborne cues to respond to flying insect predators by building orb-web with fewer silk thread and larger silk decorations," Ethology, vol. 114, no. 7, pp. 686692, 2008.

[86] M. J. Bruce, "Silk decorations: controversy and consensus," Journal of Zoology, vol. 269, no. 1, pp. 89-97, 2006.

[87] T. A. Blackledge, "Signal conflict in spider webs driven by predators and prey," Proceedings of the Royal Society B, vol. 265, no. 1409, pp. 1991-1996, 1998.

[88] T. A. Blackledge and J. W. Wenzel, "Do stabilimenta in orb webs attract prey or defend spiders?" Behavioral Ecology, vol. 10, no. 4, pp. 372-376, 1999.

[89] C. L. Craig and G. D. Bernard, "Insect attraction to ultraviolet-reflecting spider webs and web decorations," Ecology, vol. 71, no. 2, pp. 616-623, 1990.

[90] M. E. Hauber, "Web decorations and alternative foraging tactics of the spider Argiope appensa," Ethology Ecology and Evolution, vol. 10, no. 1, pp. 47-54, 1998.

[91] D. Li, M. L. M. Lim, W. K. Seah, and S. L. Tay, "Prey attraction as a possible function of discoid stabilimenta of juvenile orbspinning spiders," Animal Behaviour, vol. 68, no. 3, pp. 629635, 2004.

[92] I. M. Tso, "Stabilimentum of the garden spider Argiope trifasciata: a possible prey attractant," Animal Behaviour, vol. 52, no. 1, pp. 183-191, 1996.

[93] C. L. Craig, "Orb-web visibility: the influence of insect flight behaviour and visual physiology on the evolution of web designs within the Araneoidea," Animal Behaviour, vol. 34, no. 1, pp. 54-68, 1986.

[94] C. L. Craig, "Effects of background pattern on insect perception of webs spun by orb-weaving spiders," Animal Behaviour, vol. 39, no. 1, pp. 135-144, 1990.

[95] A. Pasquet, "Predatory-site selection and adaptation of the trap in four species of orb-weaving spiders," Biology of Behavior, vol. 9, pp. 3-19, 1984.

[96] J. W. Burgess, "Measurement of spatial behavior: methodology applied to rhesus monkeys, neon tetras, communal and solitary spiders, cockroaches, and gnats in open fields," Behavioral and Neural Biology, vol. 26, no. 2, pp. 132-160, 1979.

[97] J. W. Burgess and G. W. Uetz, "Social spacing in spiders," in Spiders Communication Mechanisms and Ecological Significance, P. Witt and J. S. Rovner, Eds., pp. 318-351, Princeton University Press, Princeton, NJ, USA, 1982.

[98] A. Pasquet, "Répartition de deux espèces d'araignées orbitèles, Araneus marmoreus (Clerk) et A. diadematus (Clerk) dans une prairie en friches," Biology of Behaviour, vol. 9, pp. 321-331, 1984.

[99] S. E. Riechert, W. G. Reeder, and T. A. Allen, "Patterns of spider distribution (Agelenopsis aperta) in desert grassland and recent lava bed habitat, South-central New Mexico," Journal of Animal Ecology, vol. 42, pp. 19-35, 1973.

[100] D. Ward and Y. Lubin, "Habitat selection and the life history of a desert spider, Stegodyphus lineatus (Eresidae)," Journal of Animal Ecology, vol. 62, no. 2, pp. 353-363, 1993.

[101] A. M. Richards, "Observations on the New Zealand glow worm Arachnocampa luminosa (Skuse)," The Transactions and Proceedings of the Royal Society of New Zealand, vol. 88, pp. 559-574, 1960.

[102] R. Brossut, Phéromones: La Communication Chimique Chez les Animaux, CNRS Editions, Paris, France, 1996.

[103] M.J. Koomans, S.W.F. Van der Ploeg, and H. Dijkstra, "Leg wave behaviour of Wolf Spiders of the genus Pardosa (Lycosidae, Araneae)," The Bulletin of the British Arachnological Society, vol. 3, pp. 53-61, 1974.

[104] G. E. Stratton and G. W. Uetz, "Communication via substratum-coupled stridulation and reproductive isolation in wolf spiders (Araneae: Lycosidae)," Animal Behaviour, vol. 31, no. 1, pp. 164-172, 1983.

[105] W. J. McClintock and G. W. Uetz, "Female choice and preexisting bias: visual cues during courtship in two Schizocosa wolf spiders (Araneae: Lycosidae)," Animal Behaviour, vol. 52, no. 1, pp. 167-181, 1996.

[106] F. G. Barth, "Sensory guidance in spider pre-copulatory behaviour," Comparative Biochemistry and Physiology, vol. 104, no. 4, pp. 717-733, 1993.

[107] F. G. Barth and A. Schmitt, "Species recognition and species isolation in wandering spiders (Cupiennius spp.; Ctenidae)," Behavioral Ecology and Sociobiology, vol. 29, no. 5, pp. 333339, 1991.

[108] D. Baurecht and F. G. Barth, "Vibratory communication in spiders-I. Representation of male courtship signals by female vibration receptor," Journal of Comparative Physiology A, vol. 171, no. 2, pp. 231-243, 1992.

[109] D. Baurecht and F. G. Barth, "Vibratory communication in spiders-II. Representation of parameters contained in synthetic male courtship signals by female vibration receptor," Journal of Comparative Physiology A, vol. 173, no. 3, pp. 309319, 1993.

[110] S. Dierkes and F. G. Barth, "Mechanism of signal production in the vibratory communication of the wandering spider Cupiennius getazi (Arachnida, Araneae)," Journal of Comparative Physiology A, vol. 176, no. 1, pp. 31-44, 1995.

[111] T. Kronestedt, "Vibratory communication in the wolf spider Hygrolycosa rubrofasciata (Araneae, Lycosidae)," Revue Suisse de Zoologie, Hors Série, pp. 341-354, 1996.

[112] J. S. Rovner and F. G. Barth, "Vibratory communication through living plants by a tropical wandering spider," Science, vol. 214, no. 4519, pp. 464-466, 1981.

[113] A. Schmitt, T. Friedel, and F. G. Barth, "Importance of pause between spider courtship vibrations and general problems 
using synthetic stimuli in behavioural studies," Journal of Comparative Physiology A, vol. 172, no. 6, pp. 707-714, 1993.

[114] A. Schmitt, M. Schuster, and F. G. Barth, "Vibratory communication in a wandering spider, Cupinnius getazi female and male preferences for features of conspecific males's releaser," Animal Behavior, vol. 48, pp. 1155-1171, 1994.

[115] W. Schuch and F. G. Barth, "Vibratory communication in a spider: female responses to synthetic male vibrations," Journal of Comparative Physiology, vol. 166, no. 6, pp. 817826, 1990.

[116] P. Boulanger, R. Leborgne, and B. Krafft, "Barrière éthologique et complémentarité des signaux chez deux espèces sympatriques de tégénaires (Araneae, Agelenidae)," Biology of Behaviour, vol. 11, pp. 145-156, 1986.

[117] B. Krafft, "The recording of vibratory signals performed by spiders during courtship," Symposium of the Zoological Society of London, vol. 42, pp. 59-67, 1978.

[118] B. Krafft, "Les systèmes de communication chez les araignées," in Proceedings of the 8th International Congress of Arachnology, pp. 197-213, Vienna, Austria, 1980.

[119] B. Krafft, "The significance and complexity of communication in spiders," in Spider Communication: Mechanisms and Ecological Significance, P. N. Witt and J. S. Rovner, Eds., pp. 15-66, Princeton University Press, Princeton, NJ, USA, 1982.

[120] B. Krafft, "Mécanismes et fonctions des communications tactochimiques et vibratoires dans les relations sexuelles, parentales et sociales chez les Araignées," Monitore Zoologico Italiano, vol. 18, pp. 169-170, 1984.

[121] B. Krafft and R. Leborgne, "Perception sensorielle et importance des phénomènes vibratoires chez les araignées," Journal de Psychologie, vol. 3, pp. 299-334, 1979.

[122] B. Krafft and T. Robert, "Remarques sur les modalités et la régulation de la communication chez les Araignées," in La Communication chez les Sociétés d'Insectes, Universidad Autonoma De Barcelona, Ed., pp. 215-225, Colloque International U.I.E.I.S., Bellaterra, 1982.

[123] R. Leborgne, "Le raprochement des sexes chez Coelotes terrestris (Wider) (Araneae, Agelenidae): étude des phénomènes vibratoires transmis par la toile lors de la rencontre des partenaires," Biology of Behaviour, vol. 11, pp. 205-216, 1986.

[124] R. Leborgne, C. Roland, and A. Horel, "Quelques aspects de la communication chimique et vibratoire chez certaines Agelenides," in Proceedings of the 8th International Congress on Arachnology, pp. 215-220, Vienna, Austria, 1980.

[125] T. Robert and B. Krafft, "Contribution à l'étude des mécanismes de la communication tacto-chimique intervenant dans le rapprochement des sexes chez Pardosa hortensis Thorell (Araneae, Lycosidae)," Atti della Società Toscana di Scienze Naturali, Memorie Serie B, vol. 88, pp. 141-153, 1981.

[126] J. R. Aldrich and T. M. Barros, "Chemical attraction of male crab spiders (Araneae, Thomisidae) and kleptoparasitic flies (Diptera, Milichiidae and Chloropidae)," Journal of Arachnology, vol. 23, no. 3, pp. 212-214, 1995.

[127] R. J. Clark and R. R. Jackson, "Dragline-mediated sex recognition in two species of jumping spiders (Araneae Salticidae), Portia labiata and P. fimbriata," Ethology Ecology and Evolution, vol. 7, no. 1, pp. 73-77, 1995.

[128] C. D. Dondale and B. M. Hedgekar, "The contact sex pheromone of Pardosa lapidicina Emerton (Araneideae, Lycosidae)," Canadian Journal of Zoology, vol. 51, pp. 400401, 1973.

[129] R. R. Jackson, "Use of pheromones by males of Phidippus johnsoni (Araneae, Saltidae) to detect subadult females that are about to molt," Journal of Arachnology, vol. 14, pp. 137139, 1986.

[130] R. R. Jackson, "Comparative study of releaser pheromones associated with the silk of jumping spiders (Araneae, Salticidae)," New Zealand Journal of Zoology, vol. 14, pp. 1-10, 1987.

[131] R. R. Jackson and K. J. Cooper, "Variability of the responses of jumping spiders (Araneae, Salticidae) to sex pheromones," New Zealand Journal of Zoology, vol. 17, pp. 39-42, 1990.

[132] B. Krafft and C. Roland, "Un labyrinthe appliqué à l'étude des attractions sociales et sexuelles et de leur spécificité chez les araignées," Revue Arachnologique, vol. 2, pp. 165-171, 1979.

[133] B. Krafft and C. Roland, "Quelques remarques au sujet de la communication chimique chez les araignées," in Comptes Rendus du Vème Colloque d'Arachnologie d'Expression Française IX, pp. 129-135, Barcelona, Spain, 1980.

[134] S. D. Pollard, A. M. Macnab, and R.R. Jackson, "Communication with chemicals: pheromones and spiders," in Ecophysiology of Spiders, W. Nentwig, Ed., pp. 133-141, Springer, Berlin, Germany, 1987.

[135] C. J. J. Richter, H. C. J. Stoling, and L. Vlijm, "Silk production in adult female of the wolf spider Pardosa amentata (Lycosidae, Araneae)," Journal of Zoology, vol. 165, pp. 285-290, 1971.

[136] C. Roland, "Chemical signals bound to the silk in spider communication (Arachnida, Aranea)," Journal of Arachnology, vol. 11, pp. 309-314, 1984.

[137] C. Roland and J. S. Rovner, "Chemical and vibratory communication in the aquatic pisaurid spider Dolomedes triton," Journal of Arachnology, vol. 11, pp. 77-85, 1983.

[138] P. W. Taylor, "Dragline-mediated mate-searching in Trite Planiceps (Araneae, Salticidae)," Journal of Arachnology, vol. 26, no. 3, pp. 330-334, 1998.

[139] W. J. Tietjen, "Dragline following by male Lycosid spiders," Psyche, vol. 84, pp. 165-178, 1977.

[140] W. J. Tietjen and J. S. Rovner, "Trail-following behaviour in two species of wolf spiders: sensory and ethoecological concomitants," Animal Behavior, vol. 28, pp. 735-741, 1980.

[141] W. J. Tietjen and J. S. Rovner, "Chemical communication in lycosid and other spiders," in Spider Communication: Mechanisms and Ecological Significance, P. N. Witt and J. S. Rovner, Eds., pp. 179-249, Princeton University Press, Princeton, NJ, USA, 1982.

[142] H. Yoshida and Y. Suzuki, "Silk as a cue for mate location in the jumping spider, Carrhotus xanthogramma (Aranea, Salticidae)," Applied Entomology and Zoology, vol. 16, pp. 315-317, 1981.

[143] B. Krafft, M. Macel, and C. Roland, "Complémentarité des signaux intervenant dans le rapprochement des sexes chez Tegenaria domestica (Agelenidae)," in Comptes Rendus, XI Colloque Européen d'Arachnologie, Tubdokumentation, vol. 38, pp. 35-40, Technische Universität Berlin, 1988.

[144] R. J. Clark and R. R. Jackson, "Self recognition in a jumping spider: Portia labiata females discriminate between their own draglines and those of conspecifics," Ethology Ecology and Evolution, vol. 6, no. 3, pp. 371-375, 1994.

[145] R. J. Clark and R. R. Jackson, "Araneophagic jumping spiders discriminate between the draglines of familiar and unfamiliar conspecifics," Ethology Ecology and Evolution, vol. 7, no. 2, pp. 185-190, 1995.

[146] M.F. Downes, "Courtship and mating in the social spider Phryganoporus candidus (Araneae, Desidae)," Bulletin of the British Arachnology Society, vol. 9, pp. 277-280, 1994. 
[147] R. R. Jackson, "Comparative studies of Dictyna and Mallos (Araneae, Dictynidae) II. The relation between courtship, mating, aggression and cannibalism in species with differing types of social organization," Revue Arachnologique, vol. 25, pp. 103-132, 1979.

[148] Y. D. Lubin, "Courtship and alternative mating tactics in a social spider," Journal of Arachnology, vol. 14, pp. 239-257, 1986.

[149] R. R. Jackson, "Male mating strategies of dictynid spiders with differing types of social organization," Symposium of the Zoological Society of London, vol. 42, pp. 79-88, 1978.

[150] H. W. Levi, "Orb weaving spiders and their webs," American Scientist, vol. 66, pp. 734-742, 1978.

[151] W. M. Masters and A. J. M. Moffat, "A functional explanation of top-bottom asymmetry in vertical orbwebs," Animal Behaviour, vol. 31, no. 4, pp. 1043-1046, 1983.

[152] S. Zschokke and F. Vollrath, "Web construction patterns in a range of orb-weaving spiders (Araneae)," European Journal of Entomology, vol. 92, no. 3, pp. 523-541, 1995.

[153] A. Aprhisiart and F. Vollrath, "Design features of the orb web of the spider, Araneus diadematus," Behavioral Ecology, vol. 5, no. 3, pp. 280-287, 1994.

[154] R. R. Jackson, "Nomenclature for orb web thread connections," The Bulletin of the British Arachnological Society, vol. 2, pp. 125-126, 1973.

[155] L. H. Lin, D. T. Edmonds, and F. Vollrath, "Structural engineering of an orb-spider's web," Nature, vol. 373, no. 6510, pp. 146-148, 1995.

[156] R. Ramousse, "Le comportement constructeur chez les araignées orbitèles," Journal Psychologie, vol. 3, pp. 217-239, 1982.

[157] S. Zschokke, "Nomenclature of the orb-web," Journal of Arachnology, vol. 27, pp. 542-546, 1999.

[158] F. Vollrath, "Analysis and interpretation of orb spider exploration and web-building behaviour," Advances in the Study of Behaviour, vol. 21, pp. 147-199, 1992.

[159] S. Zschokke and F. Vollrath, "Planarity and size of orb-webs built by Araneus diadematus (Araneae: Araneidae) under natural and experimental conditions," Ekologia Bratislava, vol. 19, no. 9993, pp. 307-318, 2000.

[160] M. König, "Beiträge zur Kenntnis des Netsbaus orbiteler Spinnen," Zeitschrift fur Tierpsychologie, vol. 8, pp. 462-493, 1951.

[161] C. F. Reed, "Cues in the web-building process," American Zoologist, vol. 9, pp. 211-221, 1969.

[162] S. Szlep, "On the plasticity of instinct of a garden spider (Aranea diadematus) construction of a cobweb," Acta Biologica Experimentalis, vol. 16, pp. 5-24, 1952.

[163] P. P. Grasse, "La reconstruction du nid et les coordinations individuelles chez Bellocositermes natalensis et Cubitermes sp. La théorie de la stigmergie: essai d'interprétation du comportement des termites constructeurs," Insectes Sociaux, vol. 6, pp. 41-84, 1959.

[164] P. J. Peters, "Orb web construction: interaction of spider (Araneus diadematus $\mathrm{Cl}$.) and thread configuration," Animal Behaviour, vol. 18, no. 3, pp. 478-484, 1970.

[165] J. Maynard Smith and S. E. Reichert, "A conflicting-tendency model of spider agonistic behaviour: hybrid pure population line comparisons," Animal Behavior, vol. 32, pp. 564-578, 1984.

[166] G. W. Uetz, "Ecology and behavior of Metepeira spinipes (Araneae, Araneidae), a colonial web-building spider from Mexico," National Geographic Research Report, no. 19, pp. 597-609, 1985.
[167] G. W. Uetz and K. R. Cangliosi, "Genetic differences in social behavior ans spacing in populations of Metepeira spinipes, a communal-territorial orb weaver (Araneae, Araneidae)," Journal of Arachnology, vol. 14, pp. 159-173, 1986.

[168] W. G. Eberhard, "The web of Uloborus diversus (Araneae, Uloboridae)," Journal of Zoology, vol. 166, pp. 417-465, 1972.

[169] W. G. Eberhard, "Behavioural flexibility in orb web construction: effects of supplies in different silk glands and spider size and weight," Journal of Arachnology, vol. 16, pp. 295-302, 1988.

[170] S. Zschokke, "Early stages of orb web construction in Araneus diadematus Clerk," Revue Suisse de Zoologie, Hors Série, pp. 709-720, 1996.

[171] S. Zschokke, "The influence of the auxiliary spiral on the capture spiral in Araneus diadematus Clerck (Araneidae)," Bulletin of the British Arachnological Society, vol. 9, pp. 169173, 1993.

[172] F. Vollrath, M. Downes, and S. Krackow, "Design variability in web geometry of an orb-weaving spider," Physiology and Behavior, vol. 62, no. 4, pp. 735-743, 1997.

[173] F. Vollrath, "Gravity as an orientation guide during webconstruction in the orb spider Araneus diadematus (Araneae, Araneidae)," Journal of Comparative Physiology A, vol. 159, no. 2, pp. 275-280, 1986.

[174] M. E. Herberstein and A. M. Heiling, "Asymmetry in spider orb webs: a result of physical constraints?" Animal Behaviour, vol. 58, no. 6, pp. 1241-1246, 1999.

[175] P. Risch, "Quantitative analysis of orb web patterns in four species of spiders," Behavior Genetics, vol. 7, no. 3, pp. 199238, 1977.

[176] P. N. Witt and C. F. Reed, "Spider-web building: measurement of web geometry identifies components in a complex invertebrate behaviour pattern," Science, vol. 149, pp. 11901197, 1965.

[177] H. M. Peters, "Maturing and coordination of web-building activity," American Zoologist, vol. 9, pp. 223-227, 1969.

[178] C. F. Reed, P. N. Witt, M. B. Scarboro, and D. B. Peakall, "Experience and the orb web," Developmental Psychobiology, vol. 3, no. 4, pp. 251-265, 1970.

[179] G. Bazante, "Action de la psilocybine, substance hallucinogène extraite de champignons du Mexique, sur l'édification des toiles d'araignées," Revue de Mycologie, vol. 36, pp. 25-46, 1971.

[180] P. Witt, C. F. Reed, and D. B. Peakall, A Spider's Web: Problems in Regulatory Biology, Springer, Berlin, Germany, 1968.

[181] P. N. Witt, "Drugs alter web-building of spiders: a review and evaluation," Behavioral Science, vol. 16, no. 1, pp. 98-113, 1971.

[182] F. Vollrath, "Altered geometry of webs in spiders with regenerated legs," Nature, vol. 328, no. 6127, pp. 247-248, 1988.

[183] S. Zschokke, "Factors influencing the size of the web in Araneus diadematus," in Proceedings of the 16th European Colloquium of Arachnology, pp. 329-334, 1997.

[184] W. G. Eberhard, "Computer simulation of orb-web construction,” American Zoologist, vol. 9, pp. 229-238, 1969.

[185] N. M. Gotts and F. Vollrath, "Artificial intelligence modelling of web-building in the garden cross spider," Journal of Theoretical Biology, vol. 152, no. 4, pp. 485-511, 1991.

[186] N. M. Gotts and F. Vollrath, "Physical and theoretical features in the simulation of animal behaviour: the spider's web," Cybernetic Systems, vol. 23, pp. 41-65, 1992.

[187] T. Krink and F. Vollrath, "Emergent properties in the behaviour of a virtual spider robot," Proceedings of the Royal Society B, vol. 265, no. 1410, pp. 2051-2055, 1998. 
[188] T. Krink and F. Vollrath, "Analysing spider web-building behaviour with rule-based simulations and genetic algorithms," Journal of Theoretical Biology, vol. 185, no. 3, pp. 321-331, 1997.

[189] T. Krink and F. Vollrath, "A virtual robot to model the use of regenerated legs in a web-building spider," Animal Behaviour, vol. 57, no. 1, pp. 223-232, 1999.

[190] A. Bernard, De l'activité individuelle à la coopération autoorganisée chez les Arthropodes: exemple de la construction chez les araignées, Thèse de l'Université Henri Poincaré NANCY I, l'Université Henri Poincaré NANCY I, 2002.

[191] M. Zunino, S. Frugis, R. Groppali, and U. Laudani, "About web building in Pholcus phalangioides Fuesslin (Araneae, Pholcidae)," Revue Arachnologique, vol. 11, pp. 123-131, 1996.

[192] E. C. Collias and N. E. Collias, "The development of nestbuilding behaviour in a weaver-bird," The Auk, vol. 81, pp. 42-52, 1964.

[193] F. Saffre, A. C. Mailleux, and J. L. Deneubourg, "Dragline attachment pattern in the neotropical social spider Anelosimus eximius (Araneae: Theridiidae)," Journal of Insect Behavior, vol. 12, no. 2, pp. 277-282, 1999.

[194] G. Theraulaz, E. Bonabeau, and J. L. Deneubourg, "The mechanisms and rules of coordinated building in social insects," in Information Processing in Social Insects, C. Detrain, J. L. Deneubourg, and J. M. Pasteels, Eds., pp. 309330, Birkhäuser, Basel, Switzerland, 1999.

[195] R. Ramousse and L. Le Guelte, "Stratégies de construction de la toile chez deux espèces d'araignées (Araneus diadematus et Zygiella x-notata)," Revue Arachnologique, vol. 5, pp. 255$265,1984$.

[196] G. W. Uetz, A. D. Johnson, and D. W. Schemske, "Web placement, web structure and prey capture in orbweaving spiders," Bulletin of the British Arachnology Society, vol. 4, pp. $141-148,1978$.

[197] C. S. Hieber, "Orb-web orientation and modification by spider Araneus diadematus and Araneus gemmoides (Araneae, Araneidae)," Journal of Insect Behavior, vol. 3, pp. 773-783, 1984.

[198] J. R. Henschel and Y. D. Lubin, "Environmental factors affecting the web and activity of a psammophilous spider in the Namib Desert," Journal of Arid Environments, vol. 22, no. 2, pp. 173-189, 1992.

[199] S. E. Riechert and R.G. Gillespie, "Habitat choice and utilization in web-building spiders," in Spiders: Webs, Behaviour and Evolution, W. A. Shear, Ed., pp. 70-120, Stanford University Press, Stanford, Calif, USA, 1986.

[200] J. M. Schneider and F. Vollrath, "The effect of prey type on the geometry of the capture web of Araneus diadematus," Naturwissenschaften, vol. 85, no. 8, pp. 391-394, 1998.

[201] W. G. Eberhard, "Effects of orb-web geometry on prey interception and retention," in Spiders: Webs, Behaviour and Evolution, W. A. Shear, Ed., pp. 70-120, Stanford University Press, Stanford, Calif, USA, 1986.

[202] R. G. Gillespie, "The role of prey availability in aggregative behaviour of the orb weaving spider Tetragnatha elongata," Animal Behaviour, vol. 35, no. 3, pp. 675-681, 1987.

[203] F. Vollrath and F. Samu, "The effect of starvation on web geometry in an orb-weaving spider," Bulletin of the British Arachnological Society, vol. 10, pp. 295-298, 1997.

[204] A. Pasquet, A. Ridwan, and R. Leborgne, "Presence of potential prey affects web-building in an orb-weaving spider Zygiella x-notata," Animal Behaviour, vol. 47, no. 2, pp. 477480, 1994.
[205] Y. Lubin and J. Henschel, "The influence of food supply on foraging behaviour in a desert spider," Oecologia, vol. 105, no. 1, pp. 64-73, 1996.

[206] S. E. Riechert, "Spider interaction strategies, communication vs coercion," in Spider Communication, Mechanisms and Ecological Significance, P. N. Witt and J. S. Rovner, Eds., pp. 281-315, Princeton University Press, Princeton, NJ, USA, 1982.

[207] R.R. Jackson, "Comparative studies of Dictyna and Mallos (Araneae, Dictynidae) I. Social organization and web characteristics," Revue Arachnologique, vol. 1, pp. 133-164, 1978.

[208] U. Seibt and W. Wickler, "Interspecific tolerance in social Stegodyphus spider (Araneae, Eresidae)," Journal of Arachnology, vol. 16, pp. 35-39, 1988.

[209] W. Wickler, "Über Koloniegrundung und soziale Bindung von Stegodyphus mimosarum Pavesi und anderen sozialen Spinnen," Zeitschrift fur Tierspychologie, vol. 32, pp. 522-531, 1973.

[210] R. E. Furey, "Two cooperatively social populations of the theridiid spider Anelosimus studiosus in a temperate region," Animal Behaviour, vol. 55, no. 3, pp. 727-735, 1998.

[211] B. Y. Main, "The biology of a social thomisid spider," Australian Entomological Society Miscellaneous Publications Supplement, no. 5, pp. 55-73, 1988.

[212] D. Rowell and L. Aviles, "Sociality in a bark-dwelling hunstman spider from Australia, Delena cancerides Walckenaer (Araneae, Sparassidae)," Insectes Sociaux, vol. 42, pp. 287302, 1995.

[213] J. W. Burgess, "Social behavior in group-living spider species," Symposium of the Zoological Society of London, vol. 42, pp. 69-78, 1978.

[214] M. D’Andrea, "Social behaviour in spiders (Arachnida, Araneae)," Monitore Zoologico Italiano, N. S. Monografia 3, 1987.

[215] B. Krafft, "Organisation et évolution des sociétés d'araignées," Journal de Psychologie, vol. 1, pp. 23-51, 1979.

[216] M. F. Downes, "The nest of the social spider Phryganoporus candidus (Araneae: Desidae): structure, annual growth cycle and host plant relationships," Australian Journal of Zoology, vol. 42, no. 2, pp. 237-259, 1994.

[217] A. L. Rypstra, "Aggregations of Nephila clavipes (Aranea, Araneidae) in relation to prey availability," Journal of Arachnology, vol. 13, pp. 71-78, 1985.

[218] J. L. Gundermann, A. Horel, and B. Krafft, "Experimental manipulations of social tendencies in the subsocial spider Coelotes terrestris," Insectes Sociaux, vol. 40, no. 2, pp. 219229, 1993.

[219] A. Horel and B. Krafft, "Le comportement maternel chez les araignées et son intervention dans les processus sociaux," Comportements, vol. 6, pp. 17-29, 1986.

[220] B. Krafft, A. Horel, and J. M. Julita, "Influence of food supply on the duration of the gregarious phase of a maternal-social spider, Coelotes terrestris (Araneae, Agelenidae)," Journal of Arachnology, vol. 14, pp. 219-226, 1986.

[221] M. A. Hodge and A. Storfer-Isser, "Conspecific and heterospecific attraction: a mechanism of web-site selection leading to aggregation formation by web-building spiders," Ethology, vol. 103, no. 10, pp. 815-826, 1997.

[222] E. M. Jakob, "Costs and benefits of group living for pholcid spiderlings: losing food, saving silk," Animal Behaviour, vol. 41, no. 4, pp. 711-722, 1991.

[223] V. Brach, "Subsocial behavior in the funnel-web wolf spider Sosippus floridanus (Araneae, Lycosidae)," The Florida Entomologist, vol. 59, pp. 225-229, 1976. 
[224] M. F. Downes, "The activity cycle of the social spider Phryganoporus candidus (Araneae, Desidae)," Bulletin of the British Arachnology Society, vol. 9, pp. 223-225, 1994.

[225] M. F. Downes, "Tolerance, interattraction and cooperation in the behaviour of the social spider Phryganoporus candidus (Araneae, Desidae)," Bulletin of the British Arachnology Society, vol. 9, pp. 309-317, 1994.

[226] A. Horel, B. Krafft, and S. Aron, "Processus de socialisation et préadaptations comportementales chez les Araignées," Bulletin de la Société Zoologique de France, vol. 121, pp. 3137, 1996.

[227] J. L. Gundermann, A. Horel, and B. Krufft, "Maternal foodsupply activity and its regulation in Coelotes terrestris (Araneae, Agelenidae)," Behaviour, vol. 107, no. 3-4, pp. 278-296, 1988.

[228] K. W. Kim and A. Horel, "Matriphagy in the spider Amaurobius ferox (Araneidae, Amaurobiidae): an example of mother-offspring interactions," Ethology, vol. 104, no. 12, pp. 1021-1037, 1998.

[229] K. W. Kim and C. Roland, "Trophic egg laying in the spider, Amaurobius ferox: mother-offspring interactions and functional value," Behavioural Processes, vol. 50, no. 1, pp. 31-42, 2000.

[230] K. W. Kim, C. Roland, and A. Horel, "Functional value of matriphagy in the spider Amaurobius ferox," Ethology, vol. 106, no. 8, pp. 729-742, 2000.

[231] R. E. Buskirk, "Coloniality, activity patterns and feeding in a tropical orb-weaving spider," Ecology, vol. 56, pp. 1314-1328, 1975.

[232] Y. D. Lubin, "Adaptive advantages and the evolution of colony formation in Cyrtophora (Araneae: Araneidae)," Zoological Journal of the Linnean Society, vol. 54, no. 4, pp. 321-339, 1974.

[233] G. W. Uetz, T. C. Kane, and G. E. Stratton, "Variation in the social grouping tendency of a communal web-building spider," Science, vol. 217, no. 4559, pp. 547-549, 1982.

[234] R. E. Buskirk, "Aggressive display and orb defense in a colonial spider, Metabus gravidus," Animal Behavior, vol. 23, pp. 560-567, 1975.

[235] M. A. Hodge and G. W. Uetz, "A comparison of agonistic behaviour of colonial web-building spiders from desert and tropical habitats," Animal Behaviour, vol. 50, no. 4, pp. 963972, 1995.

[236] H. G. Fowler and J. Diehl, "Biology of a Paraguayan colonial orb-weaver, Eriophora bistriata (Renger) (Araneae, Araneidae)," Bulletin of the British Arachnology Society, vol. 4, pp. 1241-250, 1978 .

[237] N. Gobbi, R. Zicchi, and S. F. Sakagami, "General behavioral patterns and life-cycle of the colonial spider Eriophora bistriata (Aeaneida, Argiopidae)," Boletim de Zoologia, Universidade de São Paulo, vol. 4, pp. 65-74, 1979.

[238] T. A. Evans, "Factors influencing the evolution of social behaviour in Australian crab spiders (Araneae: Thomisidae)," Biological Journal of the Linnean Society, vol. 63, no. 2, pp. 205-219, 1998.

[239] A. L. Rypstra, "Foraging flocks of spiders-a study of aggregate behavior in Cyrtophora citricola Forskål (Araneae; Araneidae) in West Africa," Behavioral Ecology and Sociobiology, vol. 5, no. 3, pp. 291-300, 1979.

[240] G. W. Uetz, "Group forating in colonial web-building spiders-evidence for risk-sensitivity," Behavioral Ecology and Sociobiology, vol. 22, no. 4, pp. 265-270, 1988.

[241] G. W. Uetz and S. C. Hieber, "Colonial web-building spiders: balancing the cost and benefits of group-living," in The
Evolution of Social Behavior in Insects and Arachnids, J. C. Choe and B. J. Crespi, Eds., pp. 458-475, Cambridge University Press, Cambridge, UK, 1997.

[242] G. W. Uetz, "The "ricochet effect" and prey capture in colonial spiders," Oecologia, vol. 81, no. 2, pp. 154-159, 1989.

[243] A. L. T. Souza, M. O. Gonzaga, and J. Vasconcellos-Neto, "Prey capture behaviour in the social spider Anelosimus eximius (Araneae: Theridiidae): responses to prey size and type," Ethology, vol. 113, no. 9, pp. 856-861, 2007.

[244] W. Nentwig, "Social spiders catch larger prey: a study of Anelosimus eximius (Araneae: Theridiidae)," Behavioral Ecology and Sociobiology, vol. 17, no. 1, pp. 79-85, 1985.

[245] A. Pasquet and B. Krafft, "Cooperation and prey capture efficiency in a social spider, Anelosimus eximius (Araneae, Theridiidae)," Ethology, vol. 90, pp. 121-133, 1992.

[246] K. S. Powers and L. Avilés, "The role of prey size and abundance in the geographical distribution of spider sociality," Journal of Animal Ecology, vol. 76, no. 5, pp. 995-1003, 2007.

[247] P. I. Ward and M. M. Enders, "Conflict and co-operation in the group feeding of the social spider Stegodyphus mimosarum," Behaviour, vol. 94, pp. 167-182, 1985.

[248] E. C. Yip, K. S. Powers, and L. Avilés, "Cooperative capture of large prey solves scaling challenge faced by spider societies," Proceedings of the National Academy of Sciences of the United States of America, vol. 105, no. 33, pp. 11818-11822, 2008.

[249] S. E. Riechert, "Why do some spiders cooperate? Agelena consociata, a case study," Florida Entomologist, vol. 68, pp. 105-113, 1985.

[250] S. E. Riechert, R. M. Roeloffs, and A. C. Echternact, "The ecology of the cooperative spider Agelena consociata in Equatorial Africa," Journal of Arachnology, vol. 14, pp. 175191, 1986.

[251] W. J. Tietjen, "Effects of colony size on web structure and behavior of the social spider Mallos gregalis," Journal of Arachnology, vol. 14, pp. 145-157, 1986.

[252] J. R. Henschel, "Predation on social and solitary individuals of the spider Stegodyphus dumicola (Araneae, Eresidae)," Journal of Arachnology, vol. 26, no. 1, pp. 61-69, 1998.

[253] L. Avilés and P. Tufino, "Colony size and individual fitness in the social spider Anelosimus eximius," American Naturalist, vol. 152, no. 3, pp. 403-418, 1998.

[254] D. Ebert, "Behavioral asymmetry in relation to body weight and hunger in the tropical social spider Anelosimus eximius (Araneae, Theridiidae)," Journal of Arachnology, vol. 26, no. 1, pp. 70-80, 1998.

[255] F. Vollrath and D. Rohde-Arndt, "Prey capture and feeding in the social spider Anelosimus eximius," Zeitschrift fur Tierpsychologie, vol. 61, pp. 334-340, 1983.

[256] J. R. Henschel, "Is solitary life an alternative for the social spider Stegodyphus dumicola?" Journal of the Namibian Scientific Society, vol. 43, pp. 71-79, 1993.

[257] B. Krafft, "Contribution à la biologie et à l'éthologie d'Agelena consociata Denis (araignée sociale du Gabon) III," Biologia Gabonica, vol. 1, pp. 3-56, 1971.

[258] T. Bilde, K. S. Coates, K. Birkhofer et al., "Survival benefits select for group living in a social spider despite reproductive costs," Journal of Evolionary Biology, vol. 20, pp. 2412-2426, 2007.

[259] M. Salomon and Y. Lubin, "Cooperative breeding increases reproductive success in the social spider Stegodyphus dumicola (Araneae, Eresidae)," Behavioral Ecology and Sociobiology, vol. 61, no. 11, pp. 1743-1750, 2007.

[260] P. P. Grasse, "Le fait social: ses critères biologiques, ses limites," in Structure et Physiologie des Sociétés Animales, 
P. P. Grasse, Ed., pp. 7-17, Colloques Internationaux du CNRS, Paris, France, 1952.

[261] P. P. Grasse, "Les phénomènes sociaux chez les animaux," Cahiers de l'Institut de Science Economique Appliquée, Supplement, no. 139, pp. 7-23, 1963.

[262] E. Kullmann, "Evolution of social behaviour in spiders (Araneae, Eresidae and Theridiidae)," American Zoologist, vol. 12, pp. 419-426, 1972.

[263] B. Krafft, "Contribution à la biologie et à l'éthologie d'Agelena consociata Denis (araignée sociale du Gabon) II," Biologia Gabonica, vol. 4, pp. 307-369, 1970.

[264] R. Leborgne and A. Pasquet, "Influences of aggregative behaviour on space occupation in the spider Zygiella $x$-notata (Clerck)," Behavioral Ecology and Sociobiology, vol. 20, no. 3, pp. 203-208, 1987.

[265] R. Leborgne and A. Pasquet, "Influence of conspecific silkstructures on the choice of a web-site by the spider Zygielle $x$-notata (Clerck)," Revue Arachnologique, vol. 7, pp. 85-90, 1987.

[266] R. R. Jackson, "Comparative studies of Dictyna and Mallos (Araneae, Dictynidae), IV: silk-mediated interattraction," Insectes Soceaux, vol. 29, pp. 15-24, 1981.

[267] T. A. Evans and B. Y. Main, "Attraction between social crab spiders: silk pheromones in Diaea socialis," Behavioral Ecology, vol. 4, no. 2, pp. 99-105, 1993.

[268] A. C. Mailleux, R. Furey, F. Saffre, B. Krafft, and J. L. Deneubourg, "How non-nestmates affect the cohesion of swarming groups in social spiders," Insectes Sociaux, vol. 55, no. 4, pp. 355-359, 2008.

[269] B. L. Bradoo, "Feeding behaviour and recruitment display in the social spider Stegodyphus sarasinorum Karsch (Araneae, Eresidae)," Tijdschrift voor Entomologie, vol. 123, pp. 89-104, 1980.

[270] R. Roeloffs and S. E. Riechert, "Dispersal and populationgenetic structure of the cooperative spider, Agelena consociata, in West African rainforest," Evolution, vol. 42, no. 1, pp. 173-183, 1988.

[271] F. Vollrath, "Colony foundation in a social spider," Zeitschrift fur Tierpsychologie, vol. 60, pp. 313-324, 1982.

[272] L. Aviles, "Newly-discovered sociality in the neotropical spider Aebutina binotata Simon (Dictynidae)," Journal of Arachnology, vol. 21, pp. 184-193, 1997.

[273] A. Bernard and B. Krafft, "L'attraction pour la soie: base de la cohésion du groupe et des comportements collectifs chez les araignées sociales," Comptes Rendus Biologie, vol. 325, pp. $1-5,2002$.

[274] F. Saffre, Dynamique et mécanismes de l'essaimage chez une araignée sociale (Anelosimus eximius), Thèse de l'Université Libre de Bruxelles, l’Université Libre de Bruxelles, 2000.

[275] F. Saffre, R. Furey, B. Krafft, and J. L. Deneubourg, "Collective decision-making in social spiders: dragline-mediated amplification process acts as a recruitment mechanism," Journal of Theoretical Biology, vol. 198, no. 4, pp. 507-517, 1999.

[276] J. L. Deneubourg and S. Goss, "Collective patterns and decision-making," Ethology Ecology and Evolution, vol. 1, pp. 295-311, 1989.

[277] A. Astudillo Fernandez, A. C. Mailleux, F. Saffre, B. Krafft, and J. L. Deneubourg, "Effect of retentive markers on the dynamics of settlement: the case of arthropod silk," Journal of Theoretical Biology, vol. 265, no. 3, pp. 411-421, 2010.

[278] P. P. Grasse, "La structure des sociétés d'invertébrés," Revue Suisse de Zoologie, vol. 53, pp. 432-441, 1946.
[279] P. P. Grasse, "Les régulations automatiques du comportement collectif des insectes sociaux et la stigmergie," Journal de Psychologie Normale et Pathologique, vol. 57, pp. 1-10, 1960.

[280] J. L. Deneubourg, S. Camazine, and C. Detrain, "Self-organization or individual complexity: a false dilemma or a true complementarity?" in Information Processing in Social Insects, C. Detrain, J. L. Deneubourg, and J. M. Pasteels, Eds., pp. 401-407, Birkhäuser, Basel, Switzerland, 1999.

[281] J. L. Deneubourg and N. R. Franks, "Collective control without explicit coding: the case of communal nest excavation," Journal of Insect Behavior, vol. 8, no. 4, pp. 417-432, 1995.

[282] N. R. Franks and J. L. Deneubourg, "Self-organizing nest construction in ants: individual worker behaviour and the nest's dynamics," Animal Behaviour, vol. 54, no. 4, pp. 779796, 1997.

[283] J. Wesley Burgess, "Web-signal processing for tolerance and group predation in the social spider Mallos gregalis simon," Animal Behaviour, vol. 27, no. 1, pp. 157-164, 1979.

[284] B. Krafft, "Eco-ethology and evolution of social spiders," in Social Insects in the Tropics, P. Jaisson, Ed., pp. 73-84, Presses Universitaires, Paris, France, 1982.

[285] B. Krafft and A. Horel, "Origin and evolution of social structures in spiders," Actes Colloques J.S.P.S. -C.N.R.S. Evolution of Animal Social Behaviour, Inuyama, pp. 25-30, 1991.

[286] W. A. Shear, "The evolution of social phenomena in spiders," The Bulletin of the British Arachnological Society, vol. 1, pp. 65-76, 1970.

[287] R. Breitwisch, "Prey capture by a West African social spider (Uloboridae: Philoponella sp.)," Biotropica, vol. 21, no. 4, pp. 359-363, 1989.

[288] W. J. Tietjen, "Social spiders webs, with special reference to the web of Mallos gregalis," in Spiders: Webs, Behaviour and Evolution, W. A. Shear, Ed., pp. 100-121, Stanford University Press, Stanford, Calif, USA, 1986.

[289] L. Aviles, "Social behaviour in a web-building lynx spider, Tapinillus spp. (Aranceae, Oxyopidae)," Biological Journal of the Linnean Society, vol. 52, no. 2, pp. 163-176, 1994.

[290] L. Avilés, W. P. Maddison, and I. Agnarsson, "A new independently derived social spider with explosive colony proliferation and a female size dimorphism," Biotropica, vol. 38, no. 6, pp. 743-753, 2006.

[291] C. Bourjot, V. Chevrier, A. Bernard, and B. Krafft, "Coordination par le biais de l'environnement: une approche biologique," in Ingénierie des Systèmes Multi-Agents, M. P. Geizes and P. Marcenac, Eds., pp. 237-250, Hermès, Paris, France, 1999.

[292] F. Saffre, B. Krafft, and J. L. Deneubourg, "A theoretical model of collective web-building in social spiders," in Ingénierie des Systèmes Multi-Agents, M. P. Geizes and P. Marcenac, Eds., pp. 237-250, Hermès, Paris, France, 1997.

[293] L. Avilés and P. Salazar, "Notes on the social structure, life cycle, and behavior of Anelosimus rupununi," Journal of Arachnology, vol. 27, no. 2, pp. 497-502, 1999.

[294] T. E. Christenson, "Behaviour of colonial and solitary spiders of the theridiid species Anelosimus eximius," Animal Behaviour, vol. 32, no. 3, pp. 725-734, 1984.

[295] B. Krafft and A. Pasquet, "Synchronized and rhythmical activity during the prey capture in the social spider Anelosimus eximius (Araneae, Theridiidae)," Insectes Sociaux, vol. 38, no. 1, pp. 83-90, 1991.

[296] G. Vakanas and B. Krafft, "Regulation of the number of spiders participating in collective prey transport in the social spider Anelosimus eximius (Araneae, Theridiidae)," Comptes Rendus Biologies, vol. 327, no. 8, pp. 763-772, 2004. 
[297] G. Vakanas, Les mécanismes de la coopération chez les Arthropodes sociaux: Etude de la prédation chez une araignée sociale, Anelosimus eximius, Thèse de l'Université Henri Poincaré Nancy I, l'Université Henri Poincaré Nancy I, 2002.

[298] G. Vakanas and B. Krafft, "Coordination of behavioral sequences between individuals during prey-capture in a social spider, Anelosimus eximius (Araneae, Theridiidae)," Journal of Insect Behavior, vol. 14, pp. 777-798, 2001.

[299] A. Dury, G. Vakanas, C. Bourjot, V. Chevrier, and B. Krafft, "Using multi-agent system to model prey capture in social spiders," in Proceedings of the 13th European Simulation Symposium (ESS '01), N. Giambiasi and C. Frydman, Eds., pp. 831-833, SCS European Publishing House, Marseille, France, 2001.

[300] F. G. Barth, "Spider senses-technical perfection and biology," Zoology, vol. 105, no. 4, pp. 271-285, 2002.

[301] O. Kraus and M. Kraus, "The genus Stegodyphus (Arachnida, Araneae). Sibling species, species groups, and parallel origin of social living," Verhandlungen des naturwissenschaftlichen Vereins in Hamburg, vol. 30, pp. 151-254, 1988.

[302] E. Kullmann, "Soziale Phaenomene bei Spinnen," Insectes Soceaux, vol. 3, pp. 289-297, 1968.

[303] D. A. Bessékon, "Intraspecific identification and tolerance in the social-maternal behaviour of Coelotes terrestris (Araneae, Agelenidae)," Behavioural Processes, vol. 39, no. 3, pp. 231239, 1997.

[304] B. Krafft, "Les interactions limitant le cannibalisme chez les araignées solitaires et sociales," Bulletin de la Société Zoologique de Franceance, vol. 2, pp. 203-221, 1975.

[305] B. Krafft and A. Horel, "Comportement maternel et relations mères-jeunes chez les araignées," Reproduction Nutrition Développement, vol. 20, pp. 747-758, 1980.

[306] A. Horel, C. Roland, and R. Leborgne, "Mise en évidence d'une tendance au groupement chez les jeunes de l'araignée solitaire Coelotes terrestris," Revue Arachnologique, vol. 2, pp. 157-164, 1979.

[307] K. W. Kim, B. Krafft, and J. C. Choe, "Cooperative prey capture by young subsocial spiders: I. Functional value," Behavioral Ecology and Sociobiology, vol. 59, no. 1, pp. 92100, 2005.

[308] C. Pleateaux-Quenu, A. Horel, and C. Roland, "A reflection on social evolution in two different groups of arthropods: halictine bees (Hymenoptera) and spiders (Arachnida)," Ethology Ecology and Evolution, vol. 9, no. 2, pp. 183-196, 1997.

[309] M. S. Blum, "Pheromonal bases of social manifestations in insects," in Pheromones, M. C. Birch, Ed., vol. 32, pp. 190199, Frontiers of Biology, North Holland, 1974. 

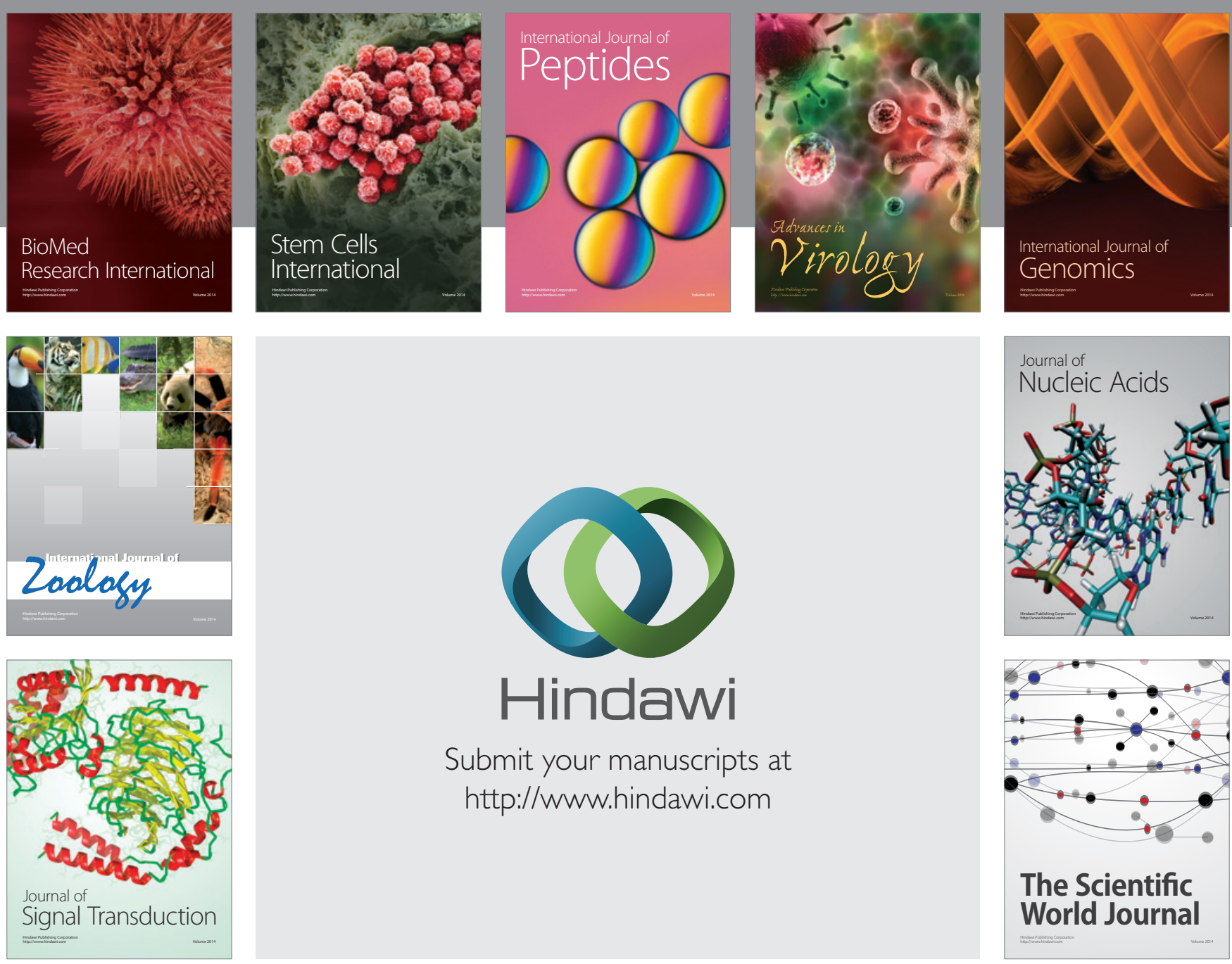

Submit your manuscripts at

http://www.hindawi.com
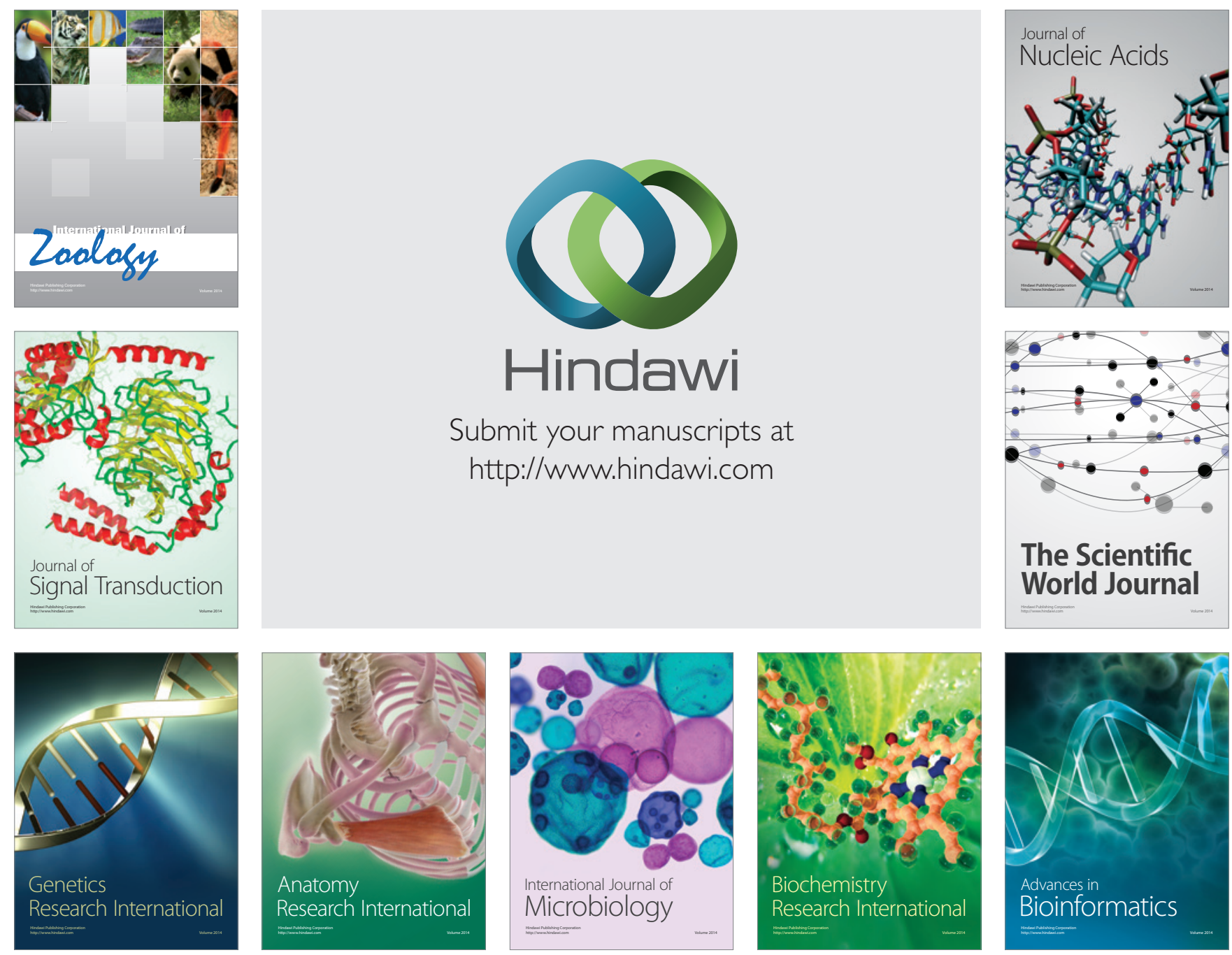

The Scientific World Journal
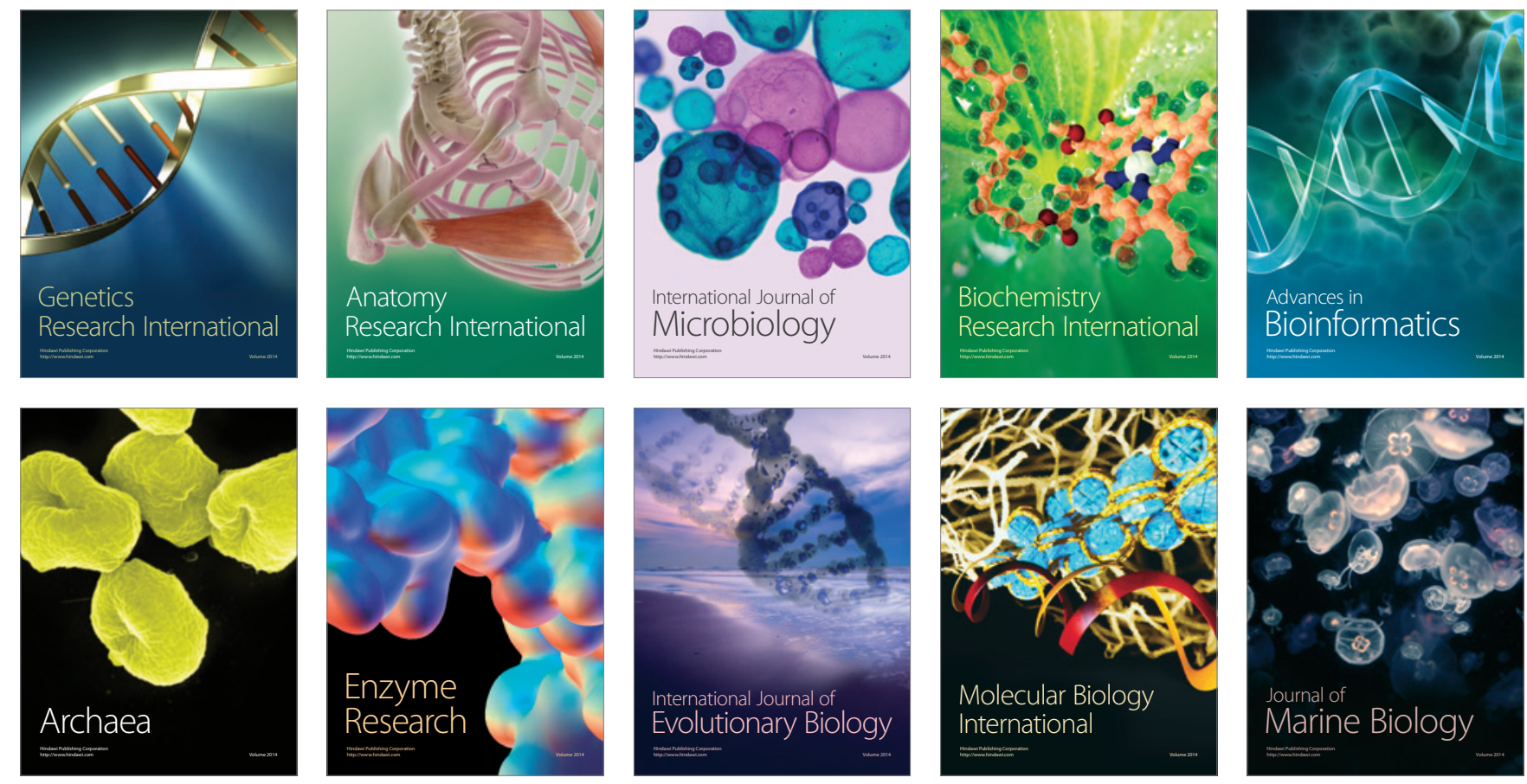